\title{
A REGIONÁLIS TUDOMÁNY „TÉRNYERÉSE": REÁLIS ESÉLYEK AVAGY CSALFA DÉLIBÁBOK?
}

\author{
('Gaining space' of Regional Science: \\ Real Chance or False Illusion?) \\ (Vitaindító tanulmány a 80 éves Enyedi György tiszteletére)
}

\author{
LENGYEL IMRE*
}

\begin{abstract}
Kulcsszavak:
regionális tudomány interdiszciplinaritás tér távolság térbeli folyamatok

A regionális tudomány nemrég ünnepelte létrejöttének félévszázados jubileumát, ezen idöszak alatt nemzetközileg széles körben elfogadottá vált. Az elmúlt két évtizedben a regionális tudomány Magyarországon is megerösödött, amiben Enyedi Györgynek múlhatatlan érdemei vannak, tudományos társaságok, intézetek, tanszékek, doktori iskolák, folyóiratok, konferenciák stb. sora jelzi a tudományág egyre szélesebb körü hazai elismertségét. De egy évtizede új kihívásokról, útkeresésröl és megújulási törekvésekröl is szólnak a szakmai viták, nemcsak külföldön, de itthon is.

Tanulmányomban** a regionális tudomány elött álló legfontosabb kihívásokkal és a lehetséges válaszokkal foglalkozom. Alapvetőnek tartom a szállitási-kommunikációs költségek drasztikus csökkenését, részben ennek hatására a térbeli kapcsolatok átrendezödését és az agglomerációs gazdaságok elötérbe kerülését. Ezek a folyamatok a globalizált gazdaság igényei szerinti új társadalmi teret formálnak, amely már jórészt elszakad a földrajzi tértöl. Véleményem szerint a regionális tudomány megújulásához nagyban hozzájárulhat a földrajzi tér és az új társadalmi tér integrált szemléletü kezelése. Reményeim szerint ez a megkettözödött tér alkalmas, Enyedi György szavaival élve, a „Föld második nagy ipari/urbanizációs hulláma" térbeli folyamatainak leirásához, illetve a terület-és településfejlesztésben általa is szorgalmazott „új paradigma koncepcionális kimunkálásához”.
\end{abstract}

Mindegyik társadalomtudománynak időnként meg kell újulnia, korábbi eredményeit „megszüntetve-megőrizve”, a változó társadalmi feltételek által felvetett régi/új kérdésekre tudományos igényủ válaszokat kell meg(újra)fogalmaznia. Nem kivétel ez alól a regionális tudomány sem, amely története során többször szembesült létét fenyegető kihívásokkal. Napjainkban ezek a kihívások főleg a globalizációs folyamatok térbeli hatásaihoz, a digitális kommunikáció elterjedéséhez köthetők, amelyek következményeként egyre erőteljesebben érzékelhető a regionális tudomány térszemléletének megújulási igénye is.

A globalizálódó gazdaság és társadalom által felvetett kérdéseket Enyedi György korán érzékelte, az 1980-as évek elején megfogalmazott, széles körben elismert urbanizációs elméletében a negyedik szakasz az informatikai korszak urbanizációja (Enyedi 1984; 1988; 1996). Az eltelt évtizedek igazolták ezt a felismerést, az informatikai-kommunikációs változások hatására pedig a „globalizált gazdaság jellemző település-térkapcsolati formája a hálózat" (Enyedi 2010, 401). De a térbeli fejlődés új mozgatórugóiról, a hálózatokról és az általuk kifeszített „új terekről” még keveset tudunk. 
Enyedi György $(2010,400)$ is a terület és településfejlesztésben „első feladatként egy új paradigma koncepcionális kimunkálását" tartja, amely a globalizációs folyamatok átfogó értelmezésén alapszik. A válság hatására más tudományokban is felerősödött az igény egy új paradigma iránt, lásd pl. a Stiglitz-Sen-Fitoussi (2010) jelentést.

Tanulmányomban először a regionális tudomány történetét tekintem át röviden, tanulságosnak tartom és további fejlődését is meghatározónak, ahogyan létrejött és müködött az elmúlt évtizedekben. Ezt követően két olyan kihívást vetek fel, amelyek napjainkban a globalizációs folyamatok következtében elötérben állnak: a „földrajzi távolság halálát” és a térbeli koncentrálódás felértékelődését. Erre a két, összefüggő kihívásra a regionális tudomány válaszai közül kettőt, a kapcsolati (hálózati) közelség vizsgálatának eredményeit és az agglomerációs előnyök újrafogalmazását ismertetem. Az új kihívásokra adott válaszok elsősorban a társadalom térbeli jellemzőinek megváltozásához, a hálózatokon alapuló új társadalmi tér kialakulásához kötődnek, amelyre több tudományág képviselői is felfigyeltek. Úgy vélem, hogy a regionális tudomány képes a kétféle, a fizikai (földrajzi) és az új társadalmi térfelfogások ötvözésére és integrált szemléletü vizsgálatára. Nemcsak képes rá, hanem ezen kétféle térszemlélet együttes kezelését tartom a regionális tudomány egyik olyan kitörési pontjának, amelynek segítségével elfogadottsága és elismertsége tovább erősödhet, nemcsak nemzetközileg, hanem itthon is.

\section{A regionális tudomány 'éretté válása}

A társadalom és gazdaság térbeli müködésének törvényszerüségeivel már régebb óta több tudományág is foglalkozik (földrajz, szociológia, filozófia stb.), de csak fél évszázada jelent meg a regionális tudomány, mint a térbeli jelenségekkel és folyamatokkal foglalkozó interdiszciplináris társadalomtudomány. Enyedi György szerint (2007, 134): ,a térfolyamatok egyes diszciplínák által tanulmányozott mechanizmusait, törvényszerüségeit, modelljeit olvasztja egy meta-szintézisbe".

A regionális tudomány öt évtizednyi 'intézményesült' történetének három nagyobb szakasza adható meg (Bailly-Gibson 2004; Boyce 2004):

- Az első szakasz az 1950-es évek elejétől az 1970-es évek elejéig tartott, amikorra a regionális tudomány megszerveződött, létrejöttek a tudományág szervezetei, folyóiratai, tanszékei, rendszeressé váltak rendezvényei stb. Fontos, hogy a korszakra széles körben jellemző keynesi gazdaságpolitikai felfogás a beruházások térben differenciált ösztönzését kiemelten kezelte, amit a hidegháborús programok is megerősítettek. Ebben az időszakban a 'gondolkozzunk térben' szemlélet elfogadottá vált és így a regionális tudomány iránti érdeklődés megélénkült, a tudományos kutatások jelentős támogatásokhoz jutottak vállalati forrásokból és közpénzekből egyaránt, az egyetemi regionális tudományi képzések iránt megnőttek az igények. 
- A második szakasz az 1970-es évek elejétől számítódik és nagyjából az 1990-es évek elejéig tartott, amikorra a regionális tudomány korábbi dinamikus fejlődése megtorpant. Ehhez hozzájárult az is, hogy a keynesi gazdaságpolitikával szemben a piaci automatizmusokat preferáló neoklasszikus közgazdasági irányzat, egyúttal a 'gondolkozzunk globálisan' szemlélet nyert teret, amely a regionális beavatkozásokat nem kezelte kiemelten. Mindez a regionális tudomány iránti érdeklődés háttérbe szorulását hozta magával és a tudományos kutatások, az egyetemi képzések anyagi és személyi feltételeinek beszükülésével járt együtt.

- A harmadik, jelenlegi szakasz az 1990-es évek elején kezdődött, amikortól a globalizáció kiváltotta térbeli folyamatok felerősödtek, a digitális kommunikációs eszközök átalakították a társadalom müködését, egyúttal a komplex fenntartható fejlődés szemlélete, a 'gondolkozzunk fenntarthatóan' elve elötérbe került. Azt is egyre szélesebb körben ismerték fel, hogy a gazdasági és társadalmi problémák sikeres megoldásához a helyi adottságokra épülő stratégiákra van szükség. Mindezek a regionális tudományban új megközelítéseket is felszínre hoztak, és a valós társadalmi problémákkal foglalkozó kutatási, oktatási programok anyagi feltételei is várhatóan (remélhetöleg?) javulnak.

A fenti három szakasz leírása kissé sematikus ${ }^{1}$, de jelzi a minden tudományra jellemző 'tudományos életciklust', amikor a kezdeti fellendülést és erőteljes terjeszkedést követően az 'érettség' időszakában megjelennek a megtorpanás jegyei ${ }^{2}$. A regionális tudomány második szakaszának végét többen válságként aposztrofálták és élénk vita folyt nemcsak a diagnózisról, hanem a terápiáról is (Bailly-Coffey-Gibson 1996).

A viták során nagyjából egyetértés körvonalazódott, miszerint a regionális tudomány megújulásához szükséges (Bailly-Coffey 1994; Benko 1999; Queigly 2001; Bailly-Gibson 2004; Capello 2008):

1) a valós társadalmi problémákra tudományosan igényesebb, a társadalom számára hasznosíthatóbb válaszok megfogalmazása, a l'art pour l'art jelleg visszaszorítása,

2) interdiszciplináris társadalomtudományi jellegének előtérbe állítása,

3) elméleti alapjainak és módszertani eszközeinek megerősítése,

4) a tudományos utánpótlás felkészítése, a mester és doktori képzések elterjesztése.

Egy új tudományág indulása és későbbi fejlődése természetesen nem függetleníthető az adott tudományág vezető egyéniségeinek, a kezdeti szervezést irányító 'mag' szerepvállalásától, érdeklődési területétől. Mint az közismert, a regionális tudomány kialakulása Walter Isard (1919-) szervező tevékenységéhez köthető, aki 1939-től a Harvardon közgazdaságtani, majd Chicago-ban matematikai és közgazdaság-elméleti tanulmányokat folytatott (Boyce 2004). Tudományos érdeklődési területének kialakulásában lényegesnek tünik, hogy az 1940-es években ő fordított le angolra több német nyelvü, alapvető elhelyezkedés-elméleti ${ }^{3}$ (location theory) munkát. A Nobel-díjas Leontief hívására részt vett a Harvard Egyetemen 1949-1953 között input-output modellek kidolgozásában, miközben a közgazdászok képzésében elhelyezkedés-elméletet és regionális fejlődési ismereteket oktatott. Érdeklődési 
területén aktív szervező munkát is végzett, 1948-tól az Amerikai Közgazdasági Társaság (AEA, American Economic Association) éves közgyülésein és egyéb rendezvényein több, regionális problémákkal foglalkozó szekciót szervezett.

Isard a MIT-re (Massachusetts Institute of Technology) 1954-ben kapott meghívást a Városi és Regionális Tervezési Tanszék (Department of City and Regional Planning) docensi (associate professor) állására regionális gazdaságtant oktatni, egyúttal a Városi és Regionális Kutatások (Section of Urban and Regional Studies) részleg igazgatója lett. Itt a közgazdász hallgatók egy érdeklődő csoportját bevonva aktív tudományszervezői munkásságot folytatott. A közgazdászokon kívül a csoport munkájában részt vettek földrajzosok, várostervezők, szociológusok stb. is. A feljegyzések szerint élénk viták folytak arról, hogy mi legyen ezen új interdiszciplináris kérdéskör neve, ami lefedi lényegét és nevében is eltér a már létező tudományágaktól. A viták során 1954-ben Isard javaslatára fogadták el a regionális tudomány (regional science) elnevezést, a Regionális Tudományi Társaság (RSA, Regional Science Association) 1954 végén tartotta elsö összejövetelét Detroit-ban (Isard 2003). Formálisan 1956-ban legitimálódott, mint társadalomtudományi tudományág, amikor csatlakozott az Társult Társadalomtudományi Társaság (Allied Social Science Association) szervezethez.

Az RSA első rendezvényein föleg a gazdaság térbeli müködésének kérdéseivel foglalkoztak, az elhelyezkedés-elméletektől, területi gazdasági elemzésektől a városfejlesztés kérdésein keresztül a regionális politikáig. Isard tevékeny közremüködésével az RSA igen intenzív tudományszervezést folytatott, rendezvények sokaságát menedzselték, folyóiratok, könyvsorozatok jöttek létre, egyetemi (master) és doktori (PhD) képzések indultak. Az 1960-as években megalakultak Európában", Ázsiában is a regionális tudományi szervezetek. A különböző kontinensek tudományos társaságait egyesítve 1990-ben jött létre a Nemzetközi Regionális Tudományi Társaság (RSAI, Regional Science Association International), a formálisan megszünő RSA jogutódjaként. A dinamikus terjeszkedésre jellemző, hogy az Európai Regionális Tudományi Társaság (ERSA, European Regional Science Association) 2010 augusztusában tartotta 50., jubileumi kongresszusát Jönköping-ben, amely rendezvényen kb. 860 előadásra került sor, köztük 9 magyar szerző tanulmányát ${ }^{5}$ fogadták el.

Az RSAI mellett a társadalomtudomány térbeli problémáival foglalkozik az Egyesült Királyságban 1985-ben megalakult Regional Studies Association, amely mára nemcsak egész Európára, hanem több kontinensre kiterjedö szerveződéssé vált. Van magyar tagszervezete is, Korompai Attila képviseli. Habár az RSAI (az ERSA) és a Regional Studies Association tagsága között van átfedés, de az éves konferenciák témáit és a folyóiratok tanulmányait áttekintve, amíg az RSAI és ERSA inkább közgazdasági modellezéssel, ökonometriával, kvantitatív területi elemzésekkel foglalkozik, addig a Regional Studies Association gyakorlatiasabb szempontból föleg társadalom- és gazdaságföldrajzi, területfejlesztési témakörökkel. Valószínű, hogy a Regional Studies Association létrejöttében és gyors elterjedésében nemcsak a regionális tudomány említett válsága játszott nagy szerepet, hanem a geográfusok útkeresése is (Mészáros 2006). A Regional Studies Association 2010-ben Pécsett szervezte éves 
konferenciáját, amelyen a 600 résztvevő közel 50 országból érkezett, a magyar kutatók $^{6} 80$ elöadást tartottak.

Megjegyzem, hogy Isard 1956-ban a MIT-röl átment az University of Pennsylvania egyetemre, Philadelphiába, mivel ott létrehozhatott egy regionális tudományi doktori $(\mathrm{PhD})$ programot, egyúttal megalapította és vezette a Regionális Tudományi Kutatóintézetet (Regional Science Research Institute), valamint nem sokkal később a Regionális Tudományi Tanszéket (Regional Science Department) is. Ezen az egyetemen regionális tudományból 1960 és 1993 között 180 fő kapott doktori fokozatot és 350 fö mester szintü diplomát (Boyce 2004). Isard 1979-ben egyetemet váltott, és átment a Cornell University-re (ahol már korábban, 1973-tól megszervezte a regionális tudományi PhD-képzést), de ekkortól már munkásságában háttérbe szorult a regionális tudomány (a Peace Science vált érdeklődésének fő területévé). Részben az ö munkahelyváltásának is betudható, hogy az University of Pennsylvania-n 1993-ban megszünt a regionális tudományi tanszék.

A regionális tudományban felmerülő föbb kérdéskörök, folyóiratokban megjelenő tanulmányok, konferencia előadások tematikus jellemzőit több vizsgálat próbálta feltárni. Az 1990-es évek elejéig a regionális tudomány 1958-ban létrehozott, első referált folyóiratában, a Journal of Regional Science-ben közölt cikkek 70\%-át közgazdászok írták, míg földrajzosok mindössze 2-3\%-át (Lengyel I.-Rechnitzer 2004, 25). A Papers of Regional Science-ben, az RSAI társasági lapjában a cikkek 30-30\%-át közgazdászok és földrajzosok, 20\%-át városkutatók és tervező szakemberek közölték, míg a többit különböző társadalomtudományi kutatók.

A regionális tudomány három bemutatott periódusának egy-egy rövidebb időszakát kiemelve megállapítható (Mera 2004): az első két periódusban a tanulmányoknak kb. harmada volt elméleti jellegü, amely arány 2001-2002-re kb. 10\%-ra esett vissza, hasonló arányt és trendet mutatnak a módszertani kutatások is, nagymértékben megnőtt viszont az alkalmazott kutatások aránya, kb. 50\%-ot elérve. Mindvégig jelentős, az írások kb. harmada foglalkozik regionális (területfejlesztési) politikai kérdésekkel. A tanulmányok témáit tekintve a gazdasági jellegüek még inkább elötérbe kerültek, a korábbi kb. 50\%-ról kétharmadra nőtt a részesedésük, a területi (földrajzi) kérdések a korábbi 40\%-ról egyharmadra csökkentek, a társadalmi jellegủ kutatások mindvégig kb. 10\%-ot tettek ki. Az adatok arra utalnak, hogy a 2000-es évek elejére egyre inkább valós társadalmi problémák vizsgálata került előtérbe.

Magyarországon a regionális tudomány intézményi hátterének megszerveződése a nyolcvanas évek közepén kezdődött. 1984-ben Enyedi György kezdeményezésére és vezetésével meglevő intézeti egységekből megalakult az MTA Regionális Kutatások Központja (RKK), pécsi székhellyel és több városban müködő részleggel. Az MTA X. Föld- és Bányászati Tudományok Osztálya osztályközi testületeként 1986 őszén alakult meg 17 fővel a Regionális Tudományos Bizottság (RTB), amelynek alapító elnöke Enyedi György, alelnöke Bartke István, titkára Nemes Nagy József volt (Horváth-Rechnitzer 2000; Rechnitzer 2009). Az RTB 1999-től a IX. Gazdaság- és Jogtudományok Osztályához tartozik, jelenleg 87 regisztrált köztestületi tagja van, akik 16 felsőoktatási intézményből (11 egyetemről 39 fo, 5 föiskoláról 7 fö), az MTA 
négy intézetéből (kiemelkedik az RKK 20 fővel) kerülnek ki, illetve az államigazgatás szervezeteiböl. Az ERSA tagszervezete a 2003-ban megalapított Magyar Regionális Tudományi Társaság (MRTT), Horváth Gyula elnökletével, és amelyet Varga Attila képvisel a nemzetközi szervezetben.

A tudományág hazai megerősödése és elismertetése szempontjából fontos, hogy regionális tudományból is lehet MTA doktora címet szerezni. 2008-tól regionális tudományi doktori iskolák müködhetnek és adhatnak doktori (PhD) fokozatot, jelenleg három egyetemen (Pécsett, Györött és Debrecenben), illetve további egyetemeken regionális tudományi témákat meghirdető doktori alprogramok működnek (Eötvös Loránd Tudományegyetem, Kaposvári Egyetem, Miskolci Egyetem, NyugatMagyarországi Egyetem, Szegedi Tudományegyetem, Szent István Egyetem). A regionális tudományi doktori iskolák két mesterszakra épülhetnek, a regionális és környezeti gazdaságtani és a vidékfejlesztési agrármérnöki mesterszakokra, mindkettőt 8-8 egyetemen akkreditálták. Az eltelt évtizedek alatt publikációs fórumok sokasága jött létre, közülük kiemelkedik az RKK kiadásában az MRTT társasági lapjaként megjelenö, 1986-ban alapított Tér és Társadalom folyóirat, illetve az Akadémiai Kiadó által gondozott 'modern regionális tudomány' könyvsorozat.

\section{Regionális tudomány: megkérdőjelezett önállóság?}

A regionális tudomány interdiszciplinaritása miatt jelentős átfedések figyelhetök meg a térbeli kérdésekkel is foglalkozó tudományágakkal, pl. közgazdaságtan, társadalomföldrajz, szociológia (Nemes Nagy 2003; McCann 2007). Szinte mindegyik regionalista két-három diszciplínában otthonos, a regionális tudomány eredményeinek döntő része több tudományág egymásra hatásából született (Rechnitzer 2005; Dusek 2007). Az interdiszciplináris társadalomtudományi jellegből szükségszerüen adódó átfedések általában kölcsönösen elönyös együttmüködéseket eredményeznek, de több esetben „határvillongások" is fellépnek. A regionális tudományt megalakulása óta a társadalomföldrajz és a közgazdaságtudomány néhány képviselöje folyamatosan bírálta. A bírálatok jelentős része jogosan mutatott rá bizonyos problémákra, fogalmi avagy módszertani hibákra. De nemcsak segítő szándékú kritikák jelentek meg, hanem többen megkérdőjelezték a regionális tudomány létjogosultságát is.

A földrajzos kritikák úgy összegezhetők, hogy a regionális tudomány fogalmai, kutatási témái, alkalmazott eszközei lényegében a széles értelemben vett társadalomföldrajz körébe tartoznak (Barnes 2003; Mészáros 2006; Probáld 2007; Beluszky 2008). Azaz nincs értelme külön tudományágról beszélni, hanem csupán a földrajztudomány, a geográfia egyik részterületéről van szó. Olyan vélemények is hallhatók, hogy máshonnan kiszorult kutatók helykeresése, ügyes tudományszervezők munkálkodása, feltörekvő kiadók kiadvány gründolása stb. áll a regionális tudomány megjelenése mögött, nem pedig a tudomány szerves önfejlődése. 
A közgazdász kritikák lényege, hogy a regionális tudomány alapvetően regionális (köz)gazdaságtan, a mainstream közgazdasági gondolatok és modellek valamilyen területi szempontú kiterjesztése. Jellemzőnek tekinthető Krugman véleménye, aki a regionális tudományról, pontosabban a regionális gazdaságtan korábbi irányzatairól elmarasztaló kritikát fogalmazott meg. Öt irányzatot részletesebben bírált (Krugman 1995; Lengyel I. 2003, 35-39): a német geometriai irányzatot (Weber-féle ipari telephely-elméletet és a Lösch-Christaller-féle központi helyek elméletét), a társadalomfizikai irányzatot (a városok népességével foglalkozó rangsor-módszerek, gravitációs modellek és potenciálmodellek), a halmozódó oksági modelleket (Hirschmann fejlődéselmélete), a lokális külső méretgazdaságosságra épülő irányzatokat (Marshall iparági körzete, illetve Henderson városrendszer modellje), valamint a földjáradék és földhasználati (Thünen-féle) modellt.

Krugman (1995) mindegyik kísérletet kudarcnak tartja abból a szempontból, hogy a regionális tudománynak ezek az eredményei nem kerültek be a közgazdászok „szakmai alapmüveltségébe”. Szerinte egyik sem lépett túl a neoklasszikus közgazdaságtan hagyományos fogalmain és eszközein, a távolság és tér lényegében exogén változóként szerepelt. Így viszont csak olyan megállapítások születhettek, amelyek a korábbi közgazdasági modellek egyszerü térbeli „szolgai kiterjesztéseként”, logikus következményeként adódtak és ezáltal nem tudták megváltoztatni a közgazdaságtan sematikus térbeli szemléletét.

A közgazdaságtanban részbeni áttörést a távolságot endogén változóként kezelö ,új gazdaságföldrajz" (NEG: new economic geography) jelentett, amely föleg Krugman, Fujita és Thisse munkásságából nőtt ki az 1990-es évek elején (Fujita-KrugmanVenables 1999). Ez az irányzat nagyban épít a városgazdaságtan és a regionális gazdaságtan néhány korábbi eredményére, Thünen gondolataira, a centrumperiféria modellre stb. A térbeliség fontosságára a figyelmet a közgazdászok körében elsősorban Krugman 2008. évi Nobel-díja hívta fel. De hasonló jelentőségünek tekinthető a gazdálkodási tudományokban Porter munkásságának elismerése, aki a vállalati, üzleti döntésekben a lokalitás, a helyi üzleti környezet szerepének fontosságát hangsúlyozza (Lengyel I. 2003). Manapság a közgazdászok a korábbiakhoz képest kevésbé kérdőjelezik meg a térbeli elhelyezkedés fontosságát, mégha többen nem is tartják fontosnak, avagy félreértik az egyes megállapításokat.

Érdekes vizsgálatot végzett Maier, Kauffman és Vyborny (2008) arra vonatkozóan, hogy önálló tudományos diszciplína-e a regionális tudomány? Különbözö társadalomtudományi diszciplínák 464 rangos folyóiratában közölt tanulmányok hivatkozásait elemezték hálózatkutatási eszközökkel. Feltevésük: egy adott diszciplína önálló, ha elkülönülése a többitől kimutatható, ha a diszciplínán belüli folyóiratok „csomósodnak”, ezen folyóiratok összekapcsolódása a hivatkozások által erős. A 10 legfontosabb regionális tudományi folyóiratot a többi 454 folyóirattal összevetve igazolták, hogy a regionális tudományi folyóiratok elkülönülnek a többi tudományágtól, a közgazdaságtantól, földrajztól, tervezéselmélettől. Ezáltal igazolhatónak vélik, hogy a regionális tudomány a többitöl jól elkülönülő diszciplína, amelynek tudományos közössége tagjai közötti kapcsolatok, a kohézió kimutatható és erős. 
Természetesen ez a vizsgálat csak egy adalék, vitatható és állandó viták tárgya, hogy mit értünk tudományág alatt, mikortól tekinthető egy irányzat önálló tudományos paradigmának, elég, ha Kuhn, Lakatos, Popper stb. közismert tudományelméleti gondolataira utalunk.

A regionális tudomány interdiszciplinaritásának érzékeltetésére érdekes adalék az RSAI elnökeinek személye ${ }^{7}$, akiket 1989-ig éves, ezt követően kétéves időszakra választanak meg. A 42 föből (Isard kétszer volt elnök, mindenki más csak egyszer) 25 fö Észak-Amerikát (24 fö Amerikai Egyesült Államok, 1 fö Kanada), 12 fö Európát (3-3 svéd és holland, 2 lengyel, 1-1 angol, német, olasz ${ }^{8}$ és svájci), 3 fö Japánt és 2 fő Ausztráliát képviselte. Kutatási területüket, végzettségüket tekintve 17 közgazdász, 14 geográfus, 7 tervező (city-planning, regional planning), és mindössze 3 személynél (Czamanski, Alonso és Boyce) szerepel a regionális tudomány és egyetlen személynél a politikatudomány.

A regionális tudomány napjainkban is zajló megújulásában ${ }^{9}$ alapvető fontosságúnak tűnik két kihívás: a „földrajzi távolság halála” és ehhez kapcsolódva a területi koncentrációk szerepének felértékelődése. Erre a két kihívásra adott válaszok a társadalom új térbeliségére is nagy hatást gyakorolnak, egyúttal lehetőséget adnak a regionális tudomány képviselőinek mind a társadalomföldrajztól, mind a közgazdaságtudománytól való markánsabb elkülönülésre.

\section{A „földrajzi távolság halála”?}

A globalizáció felerősödésével párhuzamosan két, összekapcsolódó térbeli folyamat előtérbe kerülése figyelhető meg. Egyrészt a fajlagos szállítási, közlekedési költségek csökkennek, aminek következtében a földrajzi távolság gazdasági szerepe mérséklődik, távoli üzleti partnerek között is mindennapos kapcsolatok alakulhatnak ki. Másrészt a fejlett országokban a gazdasági tevékenységek bizonyos köre térben koncentrálódik, ami a szomszédság, közelség, azaz kis távolság növekvő fontosságára utal (Enyedi 2000).

1. TÁBLÁZAT

A nemzetközi szállitási költségek 1990-es (összehasonlitható) árakon Hollandiában (Estimates of International Transport Costs (Eurocent per ton km) in 1990 prices for Various Transport Modes [The Netherlands])

\begin{tabular}{lccc}
\hline & \multicolumn{3}{c}{ Szállitási költségek (euro cent/tonnakilométer) } \\
\cline { 2 - 4 } & 1900 & 1950 & 1998 \\
\hline Vasúti szállítás & 40 & 18 & 9 \\
Belvízi hajózás & 15 & 7,5 & 6 \\
Közúti szállítás & 110 & 40 & 20 \\
Légi közlekedés & - & 750 & 44 \\
\hline
\end{tabular}

Forrás: Rietveld-Vickerman (2004, 236). 
A földrajzi távolság gazdasági szerepének átalakulását jelzik a 20. században a nemzetközi szállitási költségekben kimutatható erőteljes csökkenések is (1. táblázat). Az új technológiai megoldások és az infrastruktúra kiépülése következtében megnött a szállitás, közlekedés termelékenysége, amire utal pl. napjainkban a konténerhajók, tankerek roppant nagy mérete, avagy a 'fapados légijáratok' olcsósága.

Az elmúlt évtizedben nemcsak a tárgyak és személyek szállítási költsége, hanem a digitális infokommunikáció eszközeire (internet, mobiltelefon) épülő interaktív kommunikáció költségei is jelentösen csökkentek, a hálózati infrastruktúra kiépülése és ezen új technológiák termelékenységének ugrásszerü javulása következtében. A szolgáltatások gazdasági szerepének növekedésével a nem tárgyi (intangible) javak, információk továbbítása került előtérbe, amelyek költségei általában nem adhatók meg a földrajzi távolság függvényében (Gál 2010). Rohamosan nő a kiszervezett szolgáltatások ( $\mathrm{pl}$. call centerek), a virtuális vállalati hálózatok, a távmunka stb. szerepe. Egyre több a tudásalapú kiszervezés, pl. Indiában (Bangalore) fejlesztenek amerikai cégek megbízásából szoftvereket, komoly közös tudományos eredmények születnek egymástól távoli országokban levő, de hálózatban együttmüködő kutatócsoportok között (pl. gyógyszerek tesztelésekor). A sok országban részlegekkel bíró globális vállalatok, beszállítói hálózatok sikeressége is az interaktív infokommunikáción és az olcsó szállitáson múlik. De a személyek is egymástól távoli helyek között mobiltelefonálnak, web kamerákat használva, „egymás szemébe nézve" távbeszélgetnek, tárgyalnak stb.

A földrajzi távolság gazdasági jelentőségének háttérbe szorulása mellett a szomszédság, kis távolság felértékelödése is megfigyelhetö, azaz a területi koncentrációk, nagyvárosi térségek gazdasági szerepe is előtérbe került (Enyedi 2009). Ezt jelzi, hogy pl. 1998-ban Japán magrégiója (három prefektúra Tokió, Oszaka és Nagoja központtal) az ország területének 5\%-án terült el, a lakosság 33\%-a élt ott, akik a GDP 40\%-át állították elő (Fujita-Thisse 2002). Hasonlóan, az Európai Unió 38 legnagyobb városa 2000 -ben az EU területének 0,6\%-án a lakosság $25 \%$-át tömörítette, miközben a GDP 30\%-a itt keletkezett. Az Amerikai Egyesült Államokban 1997-ben a lakosság 53\%-a élt a negyven nagyvárosi (metropolitan) térségben, ahol a feldolgozóipari foglalkoztatottak 48\%-a dolgozott, ezen térségek az ország területének mindössze 1,9\%-át foglalták el (Henderson-Thisse 2004, xxvii). Tehát a fejlett országok gazdasági teljesítménye mögött térbeli koncentrációik, elsősorban a nagyvárosaik és vonzáskörzeteik, mint „gazdasági pólusok” állnak, amely tendencia előtérbe állította a várostudományokat is (Szirmai 2005).

Paul Krugman (2000a; 2003) szerint a térbeli koncentráció fontosságát, azaz a földrajzi közelség szerepének felértékelődését a fajlagos szállítási költségek mérséklödése, a méretgazdaságosság ${ }^{10}$, a növekvő mérethozadék ${ }^{11}$, a monopolisztikus ${ }^{12}$ térbeli verseny, illetve agglomerációs externhatások magyarázzák. Ezen hatásokból adódnak a centripetális erők, amelyek a térbeli koncentrálódást idézik elő, illetve a centrifugális erők, amelyek a térbeli diszperziót, így a két ellentétes erőhatás következtében térbeli egyensúly alakul ki. 
A csökkenő szállítási költségek és a digitális infokommunikációs technológiák elterjedése és olcsósága kapcsán az elmúlt évtizedben többen felvetették a „távolság halálát” (Jakobi 2007b; Mészáros 2008). Van, aki a „földrajzi tér összeomlásáról” (the collapse of geographic space) írt (Haggett 2006), és vannak, akik megkérdőjelezik a „földrajz eltúlzott halálát” (exaggerated death of geography) (Morgan 2004), avagy a 'távolság kimúlását' (demise of distance?) (Johnson-Siripong-Brown 2006), esetleg a 'távolság korai halálát' („death of distance” is premature) (Rietveld-Vickerman 2004).

Röviden összegezve, napjainkban a tér társadalmi-gazdasági szerepe rohamosan átalakul. Egyrészt a fajlagos szállítási költségek csökkenése és az olcsó kommunikációs lehetőségek következtében hatékonyan tudnak együttmüködni az egymástól nagy földrajzi távolságban levő egyének, üzleti partnerek is, de nem mindenkivel, nem mindenben és nem mindenhol. Másrészt a szomszédságon, közelségen alapuló koncentrálódási folyamatok egyre fontosabbá válnak, de ez a térbeli koncentrálódás sem figyelhető meg mindenütt. Kérdés, hogy milyen feltételek szükségesek a „helyfüggetlen” távolsági együttmüködéshez, kik között sikeresek és miért? De az is kérdés, hogy a térbeli koncentrálódás, a közelség előnyeinek kihasználása hol figyelhető meg és miért?

Elöször a sikeres „távolságmentes” kapcsolatoknál megfigyelhető jellemzőkre térünk ki, majd a koncentrálódást leíró agglomerációs előnyök újraértékelésére. Ezen új eredményekre alapozva ismerhetjük fel a regionális tudomány megújuló térszemléletére vonatkozó újabb javaslatokat.

\section{„, Oly távol vagy tölem (és mégis közel) "13}

A globális gazdaságban, amint áttekintettük, a szállítási és kommunikációs költségek jelentősen lecsökkentek, ez pedig lehetővé tette, hogy egymástól távoli partnerek is hatékonyan együtt tudjanak müködni. De az is nyilvánvaló, hogy a távoli kapcsolatok csak bizonyos partnerek és bizonyos helyek között állnak fenn. Több vizsgálat történt ezen „egyidejü távolsági együttmüködések” törvényszerüségeinek kimutatására, a távolság fogalmának újragondolásán, a hálózati gazdaság müködésének feltárásán túl a közelség kiterjesztett értelmezéséig.

A távolság két hely vagy két alakzat térbeli eltérésének mértéke, amely többféle módon mérhetö (Nemes Nagy 2009, 219). A légvonalbeli (szüken véve földrajzi avagy fizikai) távolságtól megkülönböztetjük a közlekedéshálózati, gazdasági (költség-) és időtávolságot, amelyek valamilyen függvényszerü (lineáris, lépcsős stb.) kapcsolatban állnak a földrajzi távolsággal (Lengyel I.-Rechnitzer 2004; Dusek-Szalkai 2006). De a fentieken kívül megjelent a szakirodalomban a kognitív, a társadalmi és a virtuális távolság is, amelyek már nem függnek a földrajzi távolságtól. A termékek, azaz tárgyi javak (és személyek) szállitásakor, pl. a feldolgozóipar dominálta ágazatoknál, a földrajzi szemléletű távolság/közelség megfelelően alkalmazható az üzleti kalkulációkhoz. De a nem tárgyi (intangible) javak, információk, a digitalizálható (kodifikált) 
tudás térbeli terjedése már nem magyarázható kielégítően a földrajzi távolsággal, pl. az infokommunikáció költségei alig függnek a partnerek térbeli elhelyezkedésétől.

A távolság hagyományos fogalma, mint két objektum térbeli eltérésének mértéke, az infokommunikációs kapcsolatok révén kirajzolódó térben nem alkalmazható. A kapcsolati, hálózati térben az üzleti együttmüködéseknél kétféle „távolság” van (Jakobi 2007a; Mészáros 2008): tartósan kapcsolatba tudunk-e kerülni valakivel, benne vagyunk-e egy interaktív kapcsolatot ápoló hálózatban, avagy nem? Ha igen, akkor „közel vagyunk egymáshoz” és lehetőség adódik a sikeres együttmüködésre, bárhol is tartózkodjunk, ha nem, akkor „végtelen távolságra vagyunk egymástól”, hiába van internetes kapcsolatunk. A hálózati tér infrastruktúráját a müszaki hálózatok és szerverek alkotják, amelyek megléte szükséges, de nem elégséges feltétel, mert a tényleges együttmüködéshez az egyének, szervezetek közötti aktív kapcsolatok is kellenek.

Ezekben a kapcsolati terekben csak az odatartozás, az interaktív kapcsolat erőssége mérhető, amely általában egy bináris (avagy néhány fokozatú) skálán adható meg. Az odatartozás és elfogadottság, a kölcsönös megértés jelenti a közelséget ${ }^{14}$, míg a nagyobb „távolság” ezekben a hálózati terekben nehezen értelmezhető, egyfajta kirekesztödésként jellemezhető (Lagendijk-Oinas 2005). A fentiek miatt vált a közelség (proximity) kulcsfogalommá a kapcsolati terekben, föleg innovatív együttmüködések esetében.

A globális tudásalapú gazdaság által formált térben a közelség új gazdasági szerepének és jellemzőinek elemzésével az innovativ miliő vizsgálatokból kiindulva többen, föleg francia kutatók foglalkoztak. A ,francia iskola” (French School of Proximity Dynamics) képviselői két alapvető tértípust, a földrajzi és kapcsolati teret, illetve hozzájuk kapcsolódva kétféle közelséget különítettek el: a földrajzi és a kapcsolati közelséget (Torre-Gilly 2000; Torre-Rallet 2005). Ebböl a megközelítésböl kiindulva Capello $(2008$, 752-753) az innovációt elösegítő endogén tényezők, mint helyi versenyelőnyök kialakulása szempontjából az alábbi három közelség típust különbözteti meg:

1) Térbeli, földrajzi közelség (spatial, geographical proximity): lehetővé teszi a gyorsabb, olcsóbb és kisebb kockázatú információcserét, a tranzakciós költségek mérséklését, a rejtett tudás elsajátítását, a lokális pozitív externhatásokat, a tudástúlcsorduláson (knowledge spillover) alapuló innovációs tevékenységeket stb., lényegében az agglomerációs előnyök érvényesülését.

2) Kapcsolati közelség (relational proximity) ${ }^{I 5}$, másképpen hálózati közelség egy adott közösség, szervezet képessége, hogy elösegítse tagjai közötti interakciók kialakulását, szervezet alatt értve a kapcsolatok bármilyen szervezett rendszerét, pl. vállalat, közigazgatás, társadalmi hálózat, szakmai közösség.

3) Intézményi közelség (institutional proximity): a formális (törvények, jogszabályok stb.) és az informális (közös nyelv, kulturális normák, tradíciók, szokások, vallás stb.) intézményi háttér viszonylag homogén üzleti környezetet hoz létre, hasonló gazdasági magatartást indukál, így ez a közelség megkönnyítheti a piaci szereplők számára az együttmúködést, támogatja az interaktív tanulási folyamatokat. 
Az előző három közelség típus szoros kapcsolatban áll, kiegészíthetik és helyettesíthetik egymást, sőt átfedések is megfigyelhetők. Az innovációk kidolgozásához szükséges interaktív tanulási folyamatban szükséges feltétel a kapcsolati közelség erőssége, azaz a hasonló tudásbázisú egyének, szervezetek közötti hatékony kommunikáció lehetősége, amely elősegítheti az innovációk létrejöttét, az abszorpciós kapacitás kialakulását, a tapasztalatok interaktív megosztását. Kapcsolati közelség fennállhat távoli városokban dolgozó szakértők, kutatók között is, pl. több telephelyes multinacionális cég részlegeinél, avagy közös tudományos projekten dolgozók között. Főleg nemzetközi összehasonlító vizsgálatoknál vették észre, hogy a sikeres együttmüködéshez fontos a kulturális normák, tradíciók, szokások ismerete, illetve a helyi intézmények müködésének „megértése”, lényegében az intézményi közelség megléte. Egy adott országon belül a széles értelemben vett intézményi háttér térben általában homogénnek tekinthető.

Nagyobb távolság esetén a kapcsolati közelség föleg akkor hatékony, ha van földrajzi „közelség-előzménye” (Boschma 2005; Torre 2008): ugyanazon korábbi munkahely, közös tanulás (egyetemeken, tréningeken, konferenciákon), több esetben családi, etnikai, vallási stb. kötelékek. Az eltelt idővel arányosan gyakran „,megkopnak” a távoli kapcsolatok, ezért időnként szükséges a „frissítésük”, azaz személyes összejöveteleken, találkozókon való újbóli megerősítésük (erre szolgálnak pl. a globális vállalatok 'összeszoktató' tréningjei, de a tudományos konferenciák is). A kapcsolati közelség csak aktív szereplőkre áll fenn, nincsenek ,potyautasok” (mint földrajzi közelségből adódó extern hatások esetében), nem lehet passzívan élvezni az előnyeit.

A közelség témakörével az elmúlt években a regionális tudomány ${ }^{16}$ képviselői közül többen foglalkoztak (lásd a szakirodalmi áttekintéseket: Polenske 2004; Lengyel I. 2008; Vas 2009). A földrajzi közelség mellett Boschma (2005) javaslata, valamint Knoben és Oerlemans (2006) rendszerezése alapján az alábbi öt típus gyakran elöfordul (Lengyel I. 2010): kognitiv közelség (hasonló tudásbázissal rendelkező, egymással kapcsolatban álló és kommunikációra képes egyének, cégek között), intézményi közelség (jogszabályok, intézmények és hasonló kulturális normák, tradíciók), szervezeti közelség (kapcsolatok szorossága a szervezeten belül avagy szervezetek között), társadalmi közelség (az egyének, szervezetek társadalmi beágyazódása, a bizalomra épülö személyes ismeretség, barátság, családi kötelékek), technológiai közelség (a technológiai tapasztalatok megoszthatósága).

Napjainkra az elérhetőség térbeli jellemzői átalakultak, amíg a szállítási költségek a termékek és személyek mozgatásánál továbbra is fontosak, addig az információk cseréjét lehetővé tevő kapcsolati közelség fenntartásának költsége elenyésző. Azt várnánk el, hogy ennek következtében az egyéb tényezők (munkaerő, ingatlanok, környezet) eltérő kínálata előidézi a térbeli kiegyenlítődést. De inkább az figyelhető meg, hogy a térbeli koncentrációk, az agglomerációs gazdaságok nem veszítettek jelentőségükből, sőt, felértékelődtek, igaz, eltérő okok miatt, amint azt Enyedi György (2009) is kiemeli. 


\section{Agglomeráció: az utolsó feltáratlan határvidék?}

Paul Krugman (1998) nevezetes mondása, miszerint a 'tér az (közgazdaságtan) utolsó feltáratlan határvidék(e)' (space: the final frontier), Ács Zoltán $(2009,51)$ újrafogalmazásában: 'az agglomeráció a (közgazdaságtan) utolsó feltáratlan határvidék(e)' (agglomeration: the final frontier). Amint néhány adattal érzékeltettük, napjaink egyik legfontosabb folyamata a területi koncentrálódás, amelynek jellemzöit a megváltozott feltételek miatt azonban újra kell értékelnünk a regionális tudományban is.

A vállalatok egymáshoz közeli elhelyezkedéséböl, azaz térbeli közelségéből származó előnyök jól ismertek, főleg Alfred Marshallnak köszönhetően, aki egy adott vállalat esetén a méretgazdaságosság vizsgálatakor két tényezőt emelt ki (Lengyel I.Mozsár 2002): a belső méretgazdaságosságot (internal economies of scale) és a külső méretgazdaságosságot (external economies of scale). A belsö méretgazdaságosságból adódó hozadék a vállalat által alkalmazott technológiától, szervezeti felépítéstől, a vezetés színvonalától stb. függő előnyök, amelyek az adott vállalatra jellemzőek, egyediek, mégha részben utánozhatók is. A külső méretgazdaságosságból eredö hozadék viszont az adott iparág ${ }^{17}$ térbeli elhelyezkedésével hozható kapcsolatba, a „hellyel”, az adott iparág cégeiből hány van ezen a településen és milyen a helyi üzleti környezet. Marshall extern hatásoknak, külső gazdasági hatásoknak nevezte ezeket az előnyöket, amelyekért a piaci szereplő nem fizet, hanem csak élvezi, és amelyek föleg szomszédsági hatásként jelentkeznek, azaz lokális kiterjedésüek és immobilak.

Marshall térgazdaságtani gondolatainak újrafelfedezése részben Krugman eredményeinek tudható be, aki a térbeli általános egyensúlyt alakító centripetális és centrifugális erők kapcsán a pozitív és negatív extern hatások szerepét egyaránt kiemelte (Krugman 2000b). Napjainkban a külső méretgazdaságosság forrásainak három csoportja figyelhető meg (Fujita-Krugman-Venables 1999; ArmstrongTaylor 2000; Lengyel I. 2010): a nagyméretü iparági piac, a specializálódó helyi munkaerőpiacok, valamint az iparági technológiai/müszaki tudás „túlcsordulása” (technological spillovers). Ezeket az extern hatásokat többen újrafogalmazták, ezért Marshall-Arrow-Romer, röviden MAR externáliaként ismertek.

A regionális tudományban a térbeli koncentrációból, a földrajzi közelségböl származó elönyöket Alfred Weber nyomán az agglomeráció ${ }^{18}$ fogalmához kötjük (McCann 2008). Az agglomerációs hozadék (agglomerációs elönyök): „a gazdasági tevékenységek során a vállalatok, illetve a tevékenységek egymáshoz közeli elhelyezkedéséből fakadó költségmegtakarítások" (Pearce 1993, 28). A neoklasszikus közgazdaságtan extern hatás fogalmával összevetve az agglomeráció föleg a regionális gazdaságtan és az üzleti (gazdálkodás) tudományok müvelöi által használt fogalom.

Hagyományosan a regionális tudományon belül Isard (1975) közismert tipizálása vált elfogadottá, amelyet Ohlin és Hoover nyomán adott, a méretgazdaságosságot és ezáltal a termelékenységet javító agglomerációs előnyök három alaptípusát megkülönböztetve (Lengyel I.-Rechnitzer 2004, 169-170): nagyvállalati (méretgazdaságossági) előnyök, lokalizációs előnyök és urbanizációs előnyök. 
A globális feltételekből és a kapcsolati tér növekvő fontosságából kiindulva Parr (2002) javasolta az agglomerációs előnyök tipizálásának megújítását. A belső és külső méretgazdaságosság mellett figyelembe vette a vállalati együttmüködések, termelési integrációk három típusát: vertikális (beszállítói hálózat, értéklánc), horizontális (egyazon iparágban tevékenykedő cégek specializációja) és párhuzamos (laterális, közös inputok alkalmazása) integrációk. Ezen integrációkból eredő iparági versenyelőnyök újabb típusai: a változatossági és a komplexitási hozadék (1. ábra).

A változatossági hozadék (economies of scope), másképpen a változatosság gazdaságossága a laterális integrációból adódik, ha egy vállalat diverzifikált termékeket, szolgáltatásokat mástól vásárolt közös modulokból, közös inputokból úgy állít elő, hogy ezen végtermékek előállítási költsége kisebb, mintha erre specializálódott cég külön-külön állítaná elő őket (Kocsis-Szabó 2001). Az összeszerelő iparokban bizonyos modulok és egységes alkatrészek tömeges gyártása kiegészül egyedi alkatrészekkel, így kis sorozatú, adott piaci szegmenst megcélzó végtermékek kedvező költséggel állíthatók elő. A komplexitásból adódó hozadék a vertikális hálózatban együttmüködő cégek egymáshoz közeli letelepedéséből adódik, föleg gyakori személyes találkozást igénylő tevékenységeknél. A méretgazdaságosság pedig főleg a horizontális hálózatokra jellemző, pl. az olasz iparági körzetekre.

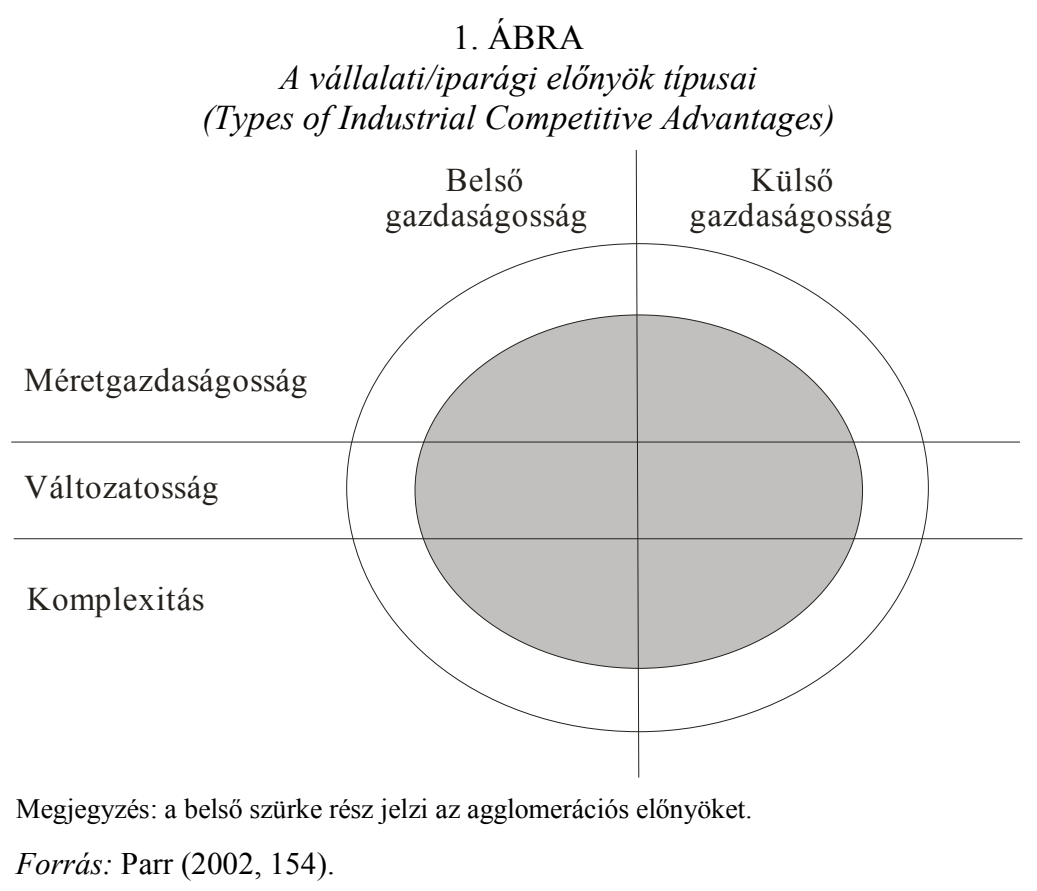

A vállalatoknak az integrációs alaptípusok mindegyikéből származhatnak versenyelőnyei (hozadékai), amelyek egy része a belső gazdaságossági (az 1. ábra bal oldala mutatja), a másik része az extern hatásokból adódó külső gazdaságossági előnyök (az 1. ábra jobb oldala mutatja). A vállalati, iparági stratégiák mindhárom 
típusából (méret, változatosság, komplexitás) nyerhetők előnyök térbeli koncentrálódás nélkül is, a kapcsolati közelséget kihasználva (az 1. ábra külső, fehér körszelete), pl. a beszállitói hálózatok sokszor szétszórva találhatók a térben. Agglomerációs előnyök szintén megjelenhetnek a belső és külső méretgazdaságosságnál, illetve mindhárom integrációnál (az 1. ábra belsö, árnyékos része).

Parr (2002) szerint a kapcsolati közelséget is figyelembe véve a földrajzi közelségböl adódó agglomerációs előnyök:

- Tevékenység-komplexitási elönyök: az értéklánc-rendszert alkotó vállalkozások egymás melletti müködésének, földrajzi közelségének, szomszédságának kihasználása, általában egy integrátor vállalat és beszállítóinak térbeli tömörülése (vertikális integráció).

- Lokalizációs előnyök (MAR extern hatások): külsők egy vállalat és belsők az adott iparág számára, azaz ugyanazon iparághoz/üzletághoz tartozó, ugyanazon tevékenységet végző vállalatok térbeli sürüsödéséből, közelségéböl származó előnyök (horizontális integráció).

- Urbanizációs elönyök (Jacobs-féle extern hatások): külsők egy vállalat és egy adott iparág számára, de belsők a térség szempontjából, általában többféle iparág/üzletág vállalatainak térbeli közelségét kihasználva a közöttük létrejövő szinergikus hatásokból adódó előnyök (laterális integráció).

A MAR-féle extern hatásokból a tudás iparág-specifikus jellege miatt (egy adott technológia fóleg ugyanazon iparágon belül hasznosítható) a specializáció fontossága adódik (Lengyel B.-Leydesdorff 2008). A nagyvárosok fejlődését vizsgálva viszont többen megállapították, hogy azok a városok sikeresebbek, ahol nemcsak adott iparágakon belüli, hanem a különböző iparágak közötti tudásáramlási hatások is erösek, mivel a technológiai diverzitásból, a különböző iparágak tudásának kereszteződéséböl (cross-fertilization) új termékek, új szolgáltatások, ezáltal új piacok jöhetnek létre (Duranton-Puga 2004; Rosenthal-Strange 2004; Combes-Mayer-Thisse 2008). A különböző iparágak térbeli közelségéből, egymásra hatásából származó tudás extern hatásokat nevezzük Jacobs-féléknek, megkülönböztetve a MAR-tól (Edwards 2007).

Ez a három agglomerációs előnyféleség első ránézésre önmagában kevés újat hoz, szinte megegyezik a régi, Isard-féle logikával. Elöre lépést jelent viszont, hogy a konkrét agglomerációk elemzése egzaktabb módon elvégezhetö, át tudunk venni a gazdálkodástudományokból (vállalati stratégiai menedzsment, termelésilánc-menedzsment, vállalati logisztika stb.) letisztult eredményeket, fogalmakat és vizsgálati eszközöket. Úgy gondolom, amíg korábban csak elnagyoltan tudtuk elemezni, föleg a város méretétől függően az egyes agglomerációs elönyöket, addig most már le lehet menni vállalati és iparági szintre, hogy ellenőrizzük hipotéziseinket. Az a felismerés is beépült a regionális tudományba, hogy sikeresek lehetnek térben szétszórt iparágak, ha élvezik a kapcsolati, hálózati közelség előnyeit. Sőt, a külső méretgazdaságosság megfigyelhető a kapcsolati térben is, elszakad a földrajzi elhelyezkedéstöl, emiatt többen értelmezték a hálózati externáliákat is (Lengyel I. 2003). 
Az agglomerációkról napjainkban is élénk vita folyik, az empirikus vizsgálatok folyamatosan zajlanak (Ejermo 2005; Beaudry-Schiffauerova 2008). Egyértelmüen kiderült, Parr javaslatát megerősítette, hogy nem érvényesülnek automatikusan az urbanizációs előnyök, mivel több nagyvárosban nem figyelhetök meg a különböző üzletágak közötti szinergiák. Az innovációk fontosságát felismerve széles körben elfogadottá vált a statikus és dinamikus agglomerációs előnyök elkülönítése (Porter 2000; Capello 2002). A statikus agglomerációs elönyök elsősorban a költségcsökkentésre lehetőséget adó hagyományos extern hatásokat jelentik. Míg a dinamikus agglomerációs előnyök föleg a tudás extern hatásokból adódnak, az innovációk kidolgozását és gyors bevezetését, a változatossági hozadékot lehetővé tevő helyi tudás túlcsordulásokat, valamint a kockázatot és bizonytalanságot mérséklő, bizalmon alapuló együttmüködéseket, interaktív tanulást teszik lehetővé.

Föleg az innovatív együttmüködéseknél, kutatói hálózatoknál figyelhető meg, hogy mind a földrajzi, mind a kapcsolati közelség hatásai egyidejüleg érvényesülnek, általában nagyon eltérő keveredésben (Csizmadia 2009; Varga-Parag 2009). Az ellentmondások elsősorban a különböző tudástípusok térbeli terjedésének eltérő sajátosságaival magyarázhatók (Lengyel B. 2004).

A hallgatólagos tudáson alapuló tevékenységek általában térben tömörülnek, a helyi együttműködések esetében fontosak a közös értékek, attitüdök, bizalom, értelmezési sémák, azaz lényegében a földrajzi és kapcsolati, intézményi közelséget egyaránt kihasználó 'helyi zsibongás' (local buzz) (2. ábra). Míg a kodifikált tudás megosztását a kapcsolati közelség a 'globális csatornákon' (global pipelines) keresztül nagy távolságban is lehetővé teszi (Bathelt 2008; Moodysson 2008). Az is lényeges, hogy a globális csatornákon zajló együttmüködések előfordulnak „elszigetelten" is, azaz egyedi partnerek a térben bárhol lehetnek, amennyiben erőteljes kapcsolati közelséget képesek kiépíteni és fenntartani.

Az innovatív kapcsolatok nem kötődnek a tervezési régiók határaihoz, sőt átléphetik az országhatárokat is, hanem inkább a spontán üzleti és személyes kapcsolatok, napi térpályák mentén alakuló csomóponti régiókban (munkaerö-piaci körzetekben) figyelhetök meg (Lengyel I. 2007; Varga 2009). Ezek a csomóponti (funkcionális) régiók három típusba sorolhatók, összhangban az agglomerációs elönyökkel (Lengyel I. 2010): nagyvárosi (urbanizációs előnyök), kisvárosi (lokalizációs elönyök) és rurális térségek.

A földrajzi és kapcsolati közelség együttes fellépésének mélyreható hatásait figyelhetjük meg, amint Enyedi György $(2009,298)$ írja, a fejlett országokban „,a modern nagyvárosi régióban különböző méretü, de egyenlő rangú települések horizontális együttmüködése váltja fel a korábbi hierarchizált tagoltságot”, és „,a tudásalapú gazdaság munkaereje jelentős részben a virtuális térben müködik, a fizikai távolságra nem érzékeny, ezért lakóhelye kiválasztásában nincs szerepe a földrajzi közelségnek". 


\section{2. ÁBRA}

A globális és lokális tudásalapú kapcsolatok térbelisége (Local Buzz and Global Pipelines in the Knowledge-based Economy)

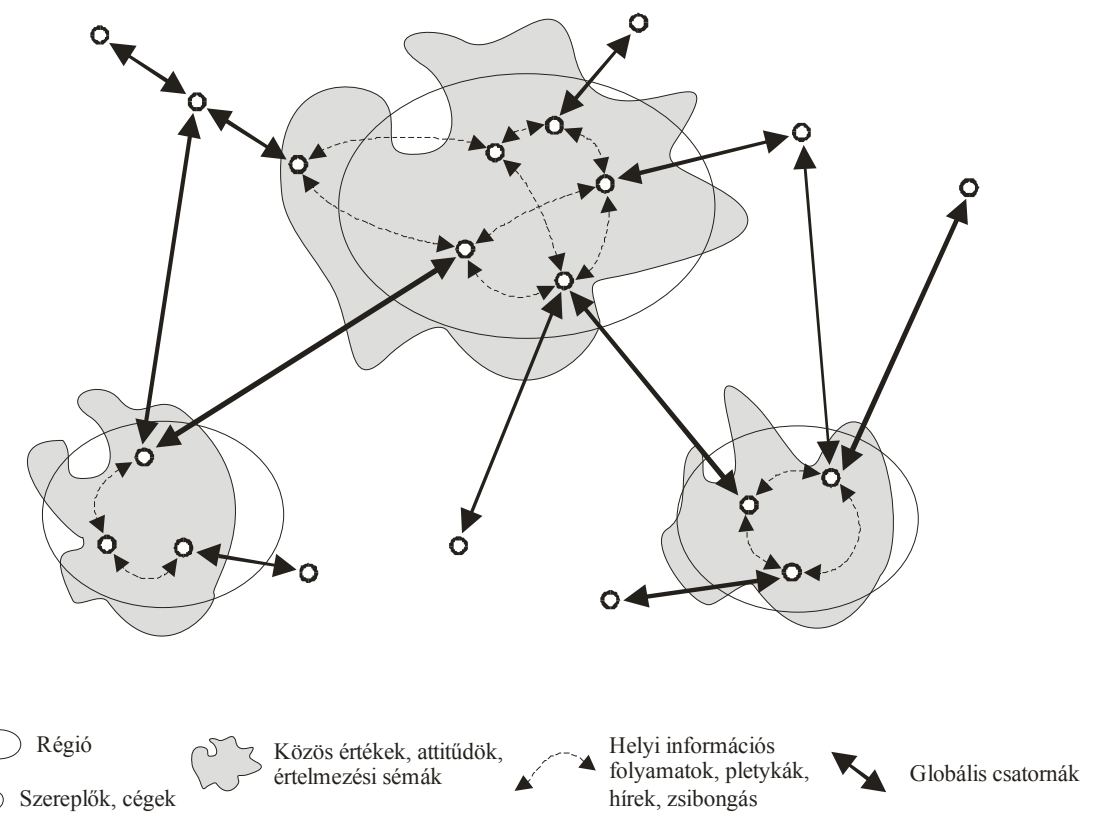

Forrás: Bathelt $(2008,88)$.

Jelenleg is élénk vita folyik az agglomerációs gazdaságokról. Krugman (2003) szerint sok hasonló adottságú hely van, ezért a térbeli koncentrációk kialakulása szinte véletlenszerü, de ha létrejöttek, akkor öngerjesztő folyamatok felerösítik őket, egyúttal ellehetetlenítve a többi potenciális helyet. Azt is megjegyzi, hogy az agglomerá-ciók helyett egyre inkább a térbeli koncentrációk kerülnek előtérbe (from agglomeration to concentration), mivel a piaci szereplök a növekvő mérethozadék kiaknázása miatt térben tömörítik a mobil tényezőket, így erősítve a térbeli centripetális erőket (Krugman 2000b, 55). Pontosabban, Krugman az urbanizációs előnyök fontosságát emeli ki a lokalizációs elönyökkel szemben. Storper és Venables (2004) szerint sem jó a lokalizációs-urbanizációs megközelítés, mert alapvetően externáliák vannak, és a növekvő mérethozadék segítségével leírható a gazdaság térbeli müködése. A regionális tudományban viszont többséginek tünik azon álláspont, hogy az 'agglomeráció' kifejezés szakszerübb és kevésbé félreérthető, mint a térbeli koncentráció, mivel utóbbit nagyon eltérő gazdasági jelenségek leírására is használhatják (Fujita-Thisse 2002, 20).

A fentieket összegezve, a globális gazdaságban a térbeli szomszédságból eredő előnyök mellett megfigyelhetők a kapcsolati közelségből eredő előnyök, amelyek elősegíthetik az egymástól távoli üzleti partnerek sikeres együttmüködését, ezek a jelenségek pedig az agglomerációs előnyök újrafogalmazását vonták maguk után. Úgy is megfogalmazható, hogy az olcsóbbá vált közlekedésre, szállításra és 
infokommunikációs eszközökre alapozva a földrajzi tér mellé felnőtt egy 'kapcsolati tér', azaz megkettőződött napjainkban a gazdaság és társadalom térbelisége. Persze az vitatható, hogy ez a kapcsolati tér, a hálózati gazdaság és társadalom mennyiben része a regionális tudomány kutatási területének?

\section{„Helyes és helytelen” terek}

A térrel kapcsolatban elmélyült és szerteágazó vizsgálatokat folytattak, többek között a filozófiában, matematikában, fizikában és földrajztudományban is (Nemes Nagy 2009). Szélesebb körben kétféle térszemlélet érhető tetten, az abszolút és a relatív térfelfogás, amelyekben a tér, az idő és a mozgás eltérő módon jelenik meg (Korompai 1995; Benedek 2002; Mészáros 2003; Jakobi 2007b; Nemes Nagy 2007). Az abszolút tér (és idő descartes-i és newtoni felfogása szerint) tőlünk függetlenül létezik, valós és változatlan, ez a háromdimenziós fizikai tér egy koordinátarendszerrel megadható, illetve térképeken ábrázolható. Ezt a felfogást haladja meg a relatív tér (és idő leibniz-i szemlélete), amelynek értelmében a tér a jelenségek, kapcsolatok egyidejű összessége, az együttlétezés rendje (Faragó 2007).

Az elmúlt évtizedekben bekövetkezett változások módosították a térbeliségről alkotott korábbi elképzeléseket, többek között a földrajztudományban, szociológiában és közgazdaságtudományban (regionális gazdaságtanban) is. A földrajztudományban Peter Haggett áttekintő müve szerint „A 'tér' (space) kiterjedést vagy területet jelent, rendszerint a földfelszín egy darabját értjük alatta" (Haggett 2006, 5). Könyvének kislexikonában a tér ,a földrajzban többjelentésü fogalom, amely utalhat egy nagy kiterjedésü, határok nélküli területre vagy egy olyan térségre, amely mérete a lokális területektől kezdve a globális földfelszínig terjed” (Haggett 2006, 803). Hasonlóan fogalmaznak a gazdaságföldrajzi bevezető egyetemi tankönyvek, pl. Mackinnon és Cumbers $(2007,3)$ szerint a tér egyszerűen a földfelszín egy része. Az Oxford Dictionary of Geography szintén csak az abszolút és relatív térfelfogást említi (Mayhew 1997, 391).

A hagyományos felfogásokon túl a társadalomföldrajzban az abszolút és relatív térszemlélet mellett megjelent három évtizede a relációs, kapcsolati tér (relational space) fogalma, amely szerint a tér társadalmi konstrukció, a társadalmi kapcsolatok, jelenségek feszítik ki (Gregory et al. 2009, 707-710). A relációs térfelfogásban a teret az emberi cselekvések alakítják, ,a tér nem semleges és passzív geometria, hanem inkább állandóan újratermelődik a társadalom és a tér egymásra hatása következtében" (Mészáros 2003, 36). Részletes áttekintésében Benedek József kiemeli, hogy a klasszikus földrajz első fázisában az abszolút térszemlélet volt jelen, az 1950-1985 közötti ,,modern földrajzi térszemlélet továbbra is az abszolút tér eszméjére épít" (Benedek 2002, 28), míg a kortárs geográfiában már megfigyelhető a relacionális (relációs) térfelfogású szemlélet. 
Az újabb társadalomföldrajzi irányzatok már erőteljesebben próbálnak elszakadni az abszolút és relatív térfelfogástól, egyre inkább elötérbe kerül a relációs térszemlélet (Mészáros 2010). A poszt-strukturalista irányzatokat áttekintve Murdoch (2006, 21-22) kiemeli: a tér nem „tartályszerü”, nem „dobozszerü” (container), hanem a diszkrét folyamatok és kapcsolatok stabilizálják, a tér többszörösen összetett kapcsolatokból épül fel, illetve a tér mindig nyitott és nem zárt. Mol és Law eredményei alapján három fő tértípust különít el (Murdoch 2006, 88): euklideszi avagy topográfiai tér (euclidean or topographical space), hálózati tér (network space) és „,cseppfolyós” tér (fluid space), utóbbi azt jelenti, hogy a szereplők közötti kapcsolatok állandó változásban, mozgásban vannak. Kiemelendők még a kibertérrel, virtuális térrel foglalkozó szerteágazó és színvonalas társadalomföldrajzi kutatások (Jakobi 2007b; Mészáros 2008).

A szociológiában a társadalom térbeliségének szerteágazó vizsgálataival találkozhatunk (A.Gergely 2001; Farkas 2003; Szirmai 2004; Bangó 2008). Castells nyomán széles körben elfogadottá vált, még az internet megjelenése elött, hogy a társadalmi szerkezet három alapvető (az ideológiai, a politikai-jogi és a gazdasági) determinánsa eltérö térszerkezetet hoznak létre (Lengyel I.-Rechnitzer 2004, 26-27). Az ideológiai (kulturális, civilizációs, nyelvi, vallási stb.) háttér egy szimbolikus teret generál, amelyen belül az egymást elfogadó egyének, közösségek között zajló kommunikáció jóval hatékonyabb, mint az eltérő ideológiai háttérrel bírók között. A politikai-jogi környezet egységes intézményi teret hoz létre (államok, közigazgatási területi egységek stb.) a hatalomgyakorlást és szabályozást megvalósító intézmények révén. A gazdasági környezet három részből áll: a munkaerőt reprodukáló fogyasztás a városokban (településekben) koncentrálódik, létrehozva a fogyasztás terét. A termékek és egyéb javak előállítása a régiókban történik, amely a termelés tere, míg a különböző városok és régiók között térbeli transzferek (jövedelmek, információk, inputok és outputok) figyelhetők meg.

Ezt a hagyományos felfogást Castells (2005) továbbdolgozta az internet elterjedését követően, kifejtve a hálózati társadalom alapgondolatait. Véleménye szerint a társadalomtudományokban ,,a tér nem a társadalom valamiféle fénymásolata, hanem maga a társadalom" (Castells 2005, 532). Munkájában a helyek által meghatározott tér hagyományos logikájával szembeállítja az áramlások terét (space of flows). Alapgondolata, hogy mai „társadalmunk különféle áramlások - tőkeáramlások, információáramlások, technológiai áramlatok, a szervezeti kölcsönhatások áramai, továbbá képek, hangok és szimbólumok áramlatai - köré szerveződik" (Castells 2005, 533).

Az áramlástér az információs társadalom három rétegének kombinációjából áll: az első réteg az elektronikus impulzusok áramkörei (infokommunikációs eszközök és hálózatok), a második réteg a csomópontok és gócpontok (specifikus helyek), míg a harmadik réteg a domináns menedzseri elit térbeli szerveződése (Castells 2005, 534-538). Az emberek továbbra is helyeken (településeken) élnek, de a hatalom és a funkciók már elváltak a helyektől. Fő hipotézise: ,a domináns funkciók az áramlások teréhez tartozó hálózatokban szerveződnek, amely világszerte összeköti őket, miközben az egyre izoláltabb, egymástól elszakított helyszínekböl (locales) 
összetevődő helyek (places) többrétegü terében az alárendelt funkciók, az emberekkel együtt fragmentálódnak" (Castells 2005, 607).

Castells gondolatai nagy hatást gyakorolnak a regionális tudományra, többek között azért, mert kiemelkedő városkutatói múlttal rendelkezik, a Berkeley Egyetemen nemcsak a szociológia, hanem a városi és regionális tervezés (City and Regional Planning) professzora is. Habár széles körben elfogadják a hálózati szerveződésnek a társadalom térbeli átalakulására gyakorolt hatását, de következtetéseit többen bírálják, az információs gazdaságban a társadalom új szerkezetéről, a kapitalizmus változó viszonyairól vallott „új baloldali” nézeteit erősen vitatják (Nyíri 1999). Természetesen a szociológiában is szerteágazó kutatások folynak, megjelentek további térszociológiai gondolatok és elemzések is (Bangó 2008).

Az eltérő térfelfogások regionális tudományi alkalmazhatóságáról kiváló áttekintést nyújt Nemes Nagy József (2009) rendszerező müvében. Megkülönbözteti az objektív (reális) tereket az észlelt (szubjektív, szemléleti), valamint virtuális terektöl. Az objektív terek egyrészt külső (fizikai, földrajzi) terek, másrészt belső (a földrajzi helytől független, a társadalmi szereplök, entitások közötti térbeli kapcsolatrendszert kifejező) terek. Véleményem szerint a külső terek az abszolút térfelfogáshoz, míg a belső terek a relációs térszemlélethez állnak közel. A két alapvető tértípus szorosan összefügg, a földrajzi (külső) tér és a különböző társadalmi (belső) terek egységet alkotnak: ,a külső és belső tér együttlétezése és megkülönböztetése a regionális tudományi szemlélet egyik legalapvetőbb elméleti momentuma" (Nemes Nagy 2009, 91). A virtuális teret ebből a megkülönböztetésből az ,információs társadalom sajátos belső terének" nevezhetjük (Nemes Nagy 2009, 103). Napjainkban, a mobil internetezés korszakában állandó viták tárgya, hogy van-e a kibertérnek térbelisége, mit nevezzünk térbeli entitásnak és hogyan lokalizálhatjuk őket?

A közgazdaságtudomány, pontosabban a regionális gazdaságtan elméleti irányzatainál alkalmazott térfelfogásokat és időbeli változásukat áttekintve Capello (2007; 2008; 2009) négyféle teret különböztet meg:

1) Fizikai-mérhetö tér (physical-metric space), amelyben a földrajzi helyek eltérései, mint távolságok jelennek meg: föleg a hagyományos elhelyezkedés-elméletekben (Thünen, Lösch, Weber, Hotelling), a vállalatok telephelyválasztásánál, a szállitási költségek, térbeli piacszerkezetek stb. vizsgálatánál alkalmazzák.

2) Egységes-absztrakt tér (uniform-abstract space), amely földrajzi elhelyezkedéstől független, kiterjedés nélküli (egy pont jellegü) régiókat feltételez (a régiókra, mint kis 'országokra' alkalmazva a nemzetgazdasági modelleket): elsősorban az állandó hozadék melletti regionális növekedési elméletekben, a munkaerő és jövedelmek régiók közötti áramlásának neoklasszikus szemléletű elemzéseiben stb. figyelhető meg.

3) Diverzifikált-kapcsolati tér (diversified-relational space), amely a régió földrajzi elhelyezkedéséből, egyedi (endogén) feltételeiből és gazdasági sajátosságaiból indul ki: az agglomerációs gazdaságok fejlődése, növekedési pólusok, regionális klaszterek kialakulása, az endogén tényezőkön alapuló egyedi fejlödési pályák, az alulról szervező stratégiák stb. kidolgozása során merül fel. 
4) Diverzifikált-stilizált tér (diversified-stylized space), amelyben a térbeli eltérés, a távolság belső (endogén) változóként jelenik meg, de még a konkrét földrajzi elhelyezkedéstől függetlenül: a térgazdaságtan újabb irányzatai, növekvő hozadék melletti regionális növekedés, térbeli egyensúlyelmélet, új gazdasági földrajz stb. modelljei.

A regionális gazdaságtannak hagyományosan három területe van: a tradicionális elhelyezkedés-elméletek (regionális mikroökonómia), a növekedéselméletek (regionális makroökonómia) és a fejlődéselméletek (fejlesztéselméletek, területfejlesztés). Capello véleménye szerint bizonyos konvergencia figyelhető meg, egyrészt az elhelyezkedés-elméletek modern irányzatai (agglomerációk, pólusok stb.) és a növekedési elméletek közelednek egymáshoz, föleg az új gazdaságföldrajz hatására (3. ábra). Másrészt a fejlődéselméletek és az elhelyezkedés-elméletek újabb irányzatai (hálózatok, klaszterek stb.) között szintén fellép egy közeledés.

\section{3. ÁBRA}

Az elméleti irányzatok konvergenciája a regionális gazdaságtanban (Convergence Among Theoretical Approaches in Regional Economics)

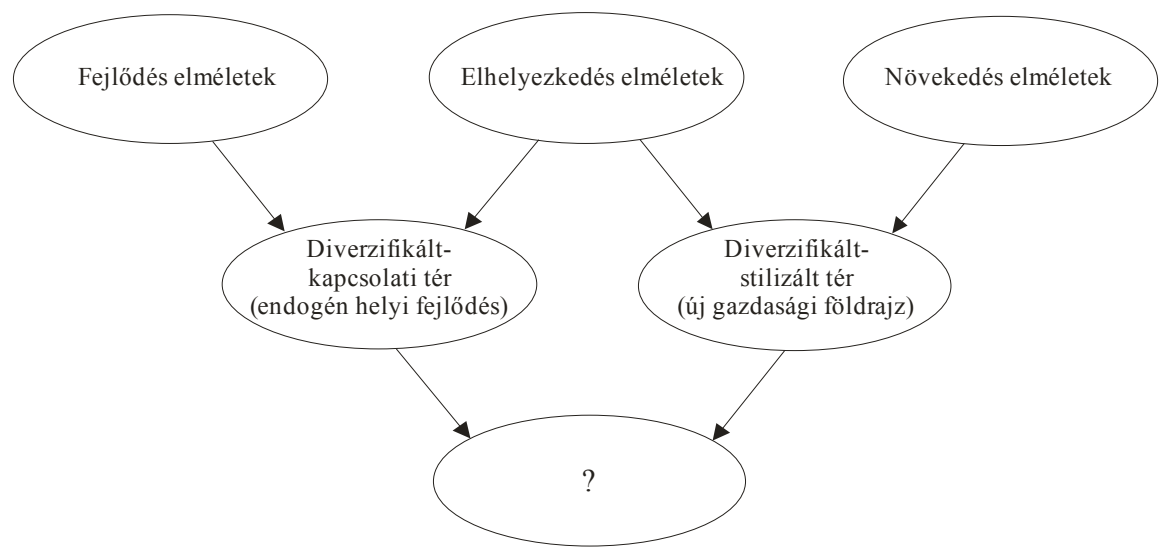

Forrás: Capello $(2009,44)$.

A fenti konvergencia hatására a regionális gazdaságtanon belül kétféle térszemlélet erősödik. Az egyik az alulról szerveződő, a helyi konkrét viszonyokra, a térbeli elhelyezkedés sajátosságaira épülő fejlődési/fejlesztési szemlélet, amely diverzifikált-kapcsolati teret feltételez. A másik a térgazdaságtani szemlélet, amelyben endogén módon megjelenik ugyan a térbeliség (és távolság), de továbbra is eltekint a konkrét földrajzi elhelyezkedéstől, a modellekben a különböző agglomerációs előnyök megjelenése viszont realisztikusabbá teszi ezt a megközelítést, emiatt a diverzifikált-stilizált térhez áll közel. Capello is kérdésként veti fel, hogy a kétféle szemlélet között a jövöben lehetséges-e közeledés, kialakul-e egységes térfelfogás?

Úgy tünik, hogy a közgazdaságtanban háttérbe szorul az absztrakt „egy pont” gazdasághoz kötődő felfogás, napjaink mérvadó irányzatainál a térbeliség markánsan tetten érhető. A diverzifikált-kapcsolati tér integrálja a társadalomföldrajzi relá- 
ciós térszemléletet, beemelve az egyedi sajátosságokat. A diverzifikált-stilizált tér közel áll a Castells-féle áramlások teréhez, amennyiben absztrakt áramlások modellezéséröl, illetve csomópontok szerepéről van szó. Természetesen Capello felvetései még csak gondolatkísérletek, nincsenek kiérlelve és bizonyítva, de a társtudományokban, illetve a regionális gazdaságtani szakirodalomban megfigyelhetö közelmúltbeli trendek véleményem szerint összhangban állnak javaslataival.

A napjainkban megfigyelhetö változások következtében, főleg a digitális forradalom hatására, alapvetően átalakult a társadalom térbeli müködése. A regionális tudomány rokontudományaiban megfigyelhető a társadalom megváltozott térbeliségéhez igazodás igénye, a társadalomföldrajz újabb irányzataiban, a szociológiában, a regionális gazdaságtanban egyaránt megjelentek azok a gondolatok és eredmények, amelyek napjaink térszerkezete további kutatásának hátteréül szolgálhatnak. De egyetértve Nemes Nagy Józseffel $(2003,5)$, „a társadalmi térelméleti kutatások nem háríthatók át semmilyen más tudományágra, ebben magáé a regionális tudományé a fö felelősség”.

\section{Regionális tudomány: vissza a jövőbe?}

A tanulmány elején közölt rövid történeti áttekintésböl is kiderült, hogy a regionális tudomány a társadalmi-gazdasági valóság és közgazdasági leírása (modelljei) között fennálló diszfunkciókból nőtt ki. Isard és kortársai érzékelték, hogy a társadalom és gazdaság térbeli összefüggéseinek megismerése iránt valós igények merültek fel, amire a közgazdászok korábban nem reagáltak, mert felfogásukat Alfred Marshall megjegyzése orientálta: „,az idő lényegesebb befolyást gyakorol a piacra, mint a tér” (idézi Benko 1999, 35).

Napjainkban alapvető strukturális változások zajlanak, amelyek a társadalom térbeli müködését gyökeresen átalakítják, a globalizáció és a digitális kommunikáció következtében új térszerkezetek formálódnak (Cséfalvay 2004). Amint bemutattuk, a regionális tudomány is reagált ezekre az új kihívásokra: egyre inkább valós társadalmi problémákra fókuszál, előtérbe került interdiszciplináris társadalomtudományi jellege, kísérletek történnek az elméleti alapok megújítására stb. De véleményem szerint továbbra is érvényes Enyedi György $(2010,401)$ megfogalmazása: „f” alapkutatási feladat: a gazdaság térbeli fejlődése új modelljének (modelljeinek) felvázolása". Lényegében a tanulmány elején már említett új paradigma koncepcionális kimunkálása, amire nemzetközileg is egyre erősebb igényt támasztott a mostani válság során felmerült problémakör.

A regionális tudomány ezen új paradigmájának, mint általában a társadalomtudományban, két pilléren kell nyugodnia: a logikán (elméleten) és az empírián (elmélet tesztelése a gyakorlatban). A tanulmányban bemutatott folyamatok és kihívások alapján az általam fontosnak tartott kutatási feladatokat három csoportra osztottam, 
az elméleti és módszertani, valamint gyakorlati jellegü kutatási kérdések mellé harmadikként odavettem az oktatást és oktatásszervezést is.

1) Elméleti és módszertani kutatások:

- Az egyik legfontosabb elméleti kutatás: a fizikai (földrajzi) tér mellé felnött, sőt dominánssá vált a társadalmi kapcsolatok terének vizsgálata, amit nevezhetünk kapcsolati, hálózati térnek (regionális gazdaságtan), relációs térnek (társadalomföldrajz) avagy áramlások terének (szociológia). De erről az új „„ársadalmi térbeliségröl”, a hálózatok térbeli szerveződéséről keveset tudunk, még kevés idő telt el a különböző elképzelések érdemi teszteléséhez és széles körủ szakmai konszenzus kialakulásához.

- Ebben az új társadalmi térben újra kell gondolnunk fogalmainkat, nemcsak az alapvető térkategóriákat, hanem mit értünk pl. területi egyenlőtlenség, területi kohézió alatt és pontosítani kellene a térbeli Paretohatékonyság elvét (a térbeli fejlödés akkor hatékony, ha egyetlen térség fejlettsége sem nőhet anélkül, hogy más térség fejlettsége ne csökkenne). Fontos annak elemzése is, hogy ebben az új térben a centrum(fél)periféria viszonyok hogyan változnak, különös tekintettel a magyar térségekre.

- Az új folyamatok vizsgálata interdiszciplináris megközelítést igényel, a nemzetközi regionális tudomány matematizált közgazdasági (fejlődési, növekedési) modelljeiben a társadalmi (szociológiai) szempontoknak is erőteljesebben meg kellene jelenniük. Itthon ezek a modellek alig ismertek, ezért a társadalomelméleti ismeretek mellett a modellezési gyakorlatnak is el kellene terjednie, hogy rokon tértudományok szakértőiböl álló teamek dolgozhassanak együtt.

- A gazdaság új térbeli fejlődési modellje szerintem nem a tervezési régiókat veszi majd alapul, hanem az agglomerációs gazdaságokat, mint csomóponti régiókat, más felfogásban városrégiókat, amelyek hálózati kapcsolatokban állnak egymással. Emiatt az agglomerációs gazdaságok kialakulásának és müködésének vizsgálata, mind a lokalizációs tudástúlcsordulások, mind az urbanizációs szinergikus hatások részletes elemzése kiemelt fontosságú, szintén tekintettel a magyar térségek sajátosságaira.

- A térbeli közelségre ható új jellemzők alapos módszertani elemzése, a szomszédság és agglomerálódás (koncentrálódás) modellezése és empirikus vizsgálata, föleg térökonometriai eszközöket alkalmazó dinamikus modellek segítségével, amely módszertani háttér nemcsak színvonalas elemzéseket tesz lehetővé, hanem a nemzetközi mainstream-hez való, a jelenleginél jóval erősebb kapcsolódást is.

2) Gyakorlathoz közeli hazai kutatások:

- Napjainkban módosulnak az állam gazdasági szerepére vonatkozó felfogások, szükség lenne az átalakuló környezetben a top-down terület- 
fejlesztési beavatkozások hatékony tervezését, intézményrendszerét és menedzselését megalapozó kutatásokra.

- A térségek közötti (együttmüködve versengő) verseny és versenyképesség hazai jellemzőinek, térségtől függő endogén tényezőinek feltárása, amire alapozva elvégezhető a bottom-up gazdaságfejlesztési stratégiák kulcselemeinek kidolgozása és az érdekeltek (kormányzati, üzleti és civil szféra) azonosítása.

- A hazai területfejlesztési politikában a különbözö irányzatok elméleti gondolatai, fogalmai és megállapításai keverednek, ami nemcsak a vitákat nehezíti meg, hanem zavarólag hat egy szélesebb körü szakmai konszenzus kialakításához is, emiatt szükséges lenne az egyes irányzatok fogalomrendszerének és eredményeinek, főleg a fejlődés- és növekedéselméletek legújabb megállapításainak szakmailag megalapozott hazai adaptációjára, a fejlesztési háttéranyagokban való megjelenítésére.

- A hazai településfejlesztés változó feltételeinek és tényezőinek vizsgálata, főleg a hálózatban együttmüködő agglomerációs gazdaságok (város-régiók) fejlesztési kérdéseinek elemzése, összhangban a településhálózat jövőbeni fejlesztésére vonatkozó elképzelések szakmai megalapozásával.

- Szükséges annak elemzése, hogy az új térfolyamatok hogyan hatnak a környezeti szempontú fenntartható fejlödésre, föleg a fenntartható településfejlesztés alapvető kérdéseire.

3) Oktatási és oktatásszervezési kérdések:

- A meglevő regionalista mesterszakok elismertségének növelése, nemcsak a leendö hallgatók, hanem a munkaadók körében is, mivel ezek az új mesterszakok még nem ismertek, szükség lenne hatékony megjelenítésükre a médiában és egyéb fórumokon.

- Az egyetemen, föiskolákon a regionális mühelyek, tanszékek megerősitése, a fóállású vezető oktatók körének kibővítése, egyúttal az egyetemeken belül, a szakok (lényegében tanszékek) közötti (időnként kiszorító) versengésben a pozícióink megerősítése, továbbá ezen felsőoktatási regionalista mühelyek hálózati együttmüködésének és nemzetközi kapcsolatainak megerösítése.

- A közgazdasági, üzleti alapképzésekben a térbeli, földrajzi ismeretek, a geográfusoknak pedig gazdasági, üzleti és társadalmi ismeretek alaposabb oktatására lenne szükség. A megfelelő módon, didaktikailag jól felépített és a modern nemzetközi irányzatok eredményeit, az idegen nyelvü kifejezéseket pontosan visszaadó, széles körben oktatható egyetemi tankönyvek (fordítások) kellenek.

- A doktori témaválasztásnál jelenleg föleg a leíró témák dominálnak, erős társadalomföldrajzi szemlélettel és fogalomhasználattal, nagyobb arányban kellene a regionális tudomány nemzetközi fórumai által prefe- 
rált deduktív elméletalkotáson (hipotéziseken) nyugvó, empirikusan tesztelhető magyarázó modellek vizsgálatát témaként meghirdetni.

- A regionális tudomány jövőbeni bázisát alkotó doktoranduszok, kiemelkedö képességü mesterszakos hallgatók számára nyári egyetemek, szakmai vetélkedők megszervezésére, publikációs fórumok kialakítására lenne szükség.

Úgy vélem, hogy a regionális tudomány elött sok megoldandó kutatási és szervezési feladat áll, de kardinális kutatási kérdésnek a gazdaság új térbeli fejlődési modelljének vizsgálatát, a fizikai (földrajzi) és társadalmi térfelfogás szintézisét tartom. Amint kitértünk rá, ezeket a tereket különböző diszciplínák vizsgálják, a fizikai teret főleg a földrajz, a társadalmi tereket a szociológia, az absztrakt gazdasági teret a közgazdaságtudomány (térgazdaságtan) stb. De a hagyományos diszciplínák nehezen lépik át megcsontosodott kutatási határaikat, a kétféle térfelfogás szerves egységét (Nemes Nagy megfogalmazásában: a külső és belső terek egységét) véleményem szerint a regionális tudomány képes visszaadni, mint többféle szakma eredményeit és kutatóit integráló társadalmi tértudomány.

Persze vitatható, hogy a társadalom új térbeliségéről sokféleképpen megnyilvánuló, most formálódó irányzatok eredményeit lehet-e egységes elméletbe integrálni? Ha igen, akkor a regionális tudomány lesz-e, amelyik ezt a szintézist képes létrehozni? Remélhetőleg igen, a regionális tudomány megújulásához és széles körü elfogadtatásához ez az integráló szerep az egyik legnagyobb lehetőség, ha élni tudunk vele, akkor „teret nyerünk”. Enyedi György $(2003,159)$ alkalmazott földrajzról kifejtett gondolatai most is érvényesek, ne „,csak azt keressük, hogy mi a gyakorlat kereslete, hanem magunk fogalmazzuk meg - és vigyük piacra - saját kínálatunkat”.

Vajon leírja-e és mikor egy regionalista az apjának írt levelében, miként Bolyai János: "Semmiből egy más, új világot teremtettem"? Avagy nem tudunk élni a társadalmi tértudományi eredmények integrálásával, mint reális eséllyel és csalfa délibábként megcsalnak a regionális tudomány jövöjéről szött nagyreményủ álmaink? A fenti kérdésekre Enyedi György $(2009,302)$ szavaival élve „csak egy francia mondással válaszolhatok: qui vivra, verra - aki megéli, meglátja".

\section{Jegyzetek}

* Dr. Lengyel Imre, az MTA doktora, az MTA Regionális Tudományos Bizottság elnöke, intézetvezető egyetemi tanár, Szegedi Tudományegyetem Gazdaságtudományi Kar Közgazdaságtani és Gazdaságfejlesztési Intézet, Szeged. E-mail: ilengyel@eco.u-szeged

** A kézirat korábbi változatához többen füztek megjegyzéseket, ezúton is köszönöm Bajmócy Zoltán, Lengyel Balázs, Lukovics Miklós, Málovics György és Rechnitzer János értékes segítségét.

1 A regionális tudomány, mint társadalomtudomány nem független a vizsgálatának tárgyát alkotó társadalmi-gazdasági folyamatoktól, szakaszoktól, amelyek többféle módon, így pl. a Kondratyevciklusokkal is megragadhatók. A vázolt három, főleg az USÁ-ra jellemző szakaszoktól eltér az európai gyakorlat, ahol 1987 után a regionális politika igényelte a regionális tudomány bizonyos eredményeit, mégha annak csak egy szük kérdéskörével is, föleg a területfejlesztéssel kapcsolatban. 
${ }^{2}$ Boyce (2004) a regionális tudomány történetét feldolgozó alapos munkájában a fentiektől kissé eltérve a nemzetközi szervezetek megalakulásához és terjeszkedéséhez köti a szakaszokat: 1954-től 1968-ig a 'kezdeti évek', 1968-1989 között a 'terjeszkedés évei', míg 1990-2003 között az 'érettség évei'.

${ }^{3}$ A 'location theory' fordítása telephelyelmélet, telephelyválasztás stb. szokott lenni, amelyek a magyar nyelvben azonban nem adják vissza a fogalom lényegét, legalábbis az én felfogásomban a 'telep' inkább egy nagyobb vállalat térben elkülönülö részlegét jelenti (közel 5 évet dolgoztam egy többtelephelyes vállalatnál, ami nyilván befolyásolja szemléletemet). Az 'elhelyezkedés-elmélet' kifejezés talán jobban megfeleltethető a fogalom valós tartalmának.

4 A volt szocialista országokban elsőnek Krakkóban, 1965-ben tartottak európai regionális tudományi kongresszust, a másodikat 1968 augusztusának végén Budapesten. Ez a rendezvény a Varsói Szerződés csapatainak Csehszlovákiába történő bevonulását csak pár nappal követte, emiatt több nyugati ország regionalistái bojkottálták. Csak 1975-ben szünt meg a bojkott és szerveződött meg újra az egész Európára kiterjedő kongresszus, ismét Budapesten (Boyce 2004).

5 Lásd az RTB hírleveleit: http://www.eco.u-szeged.hu/karunkrol/kozgazdasagtani/mta-regionalistudomanyos

6 Szintén lásd az RTB hírleveleit: http://www.eco.u-szeged.hu/karunkrol/kozgazdasagtani/mtaregionalis-tudomanyos

${ }^{7}$ Lásd: http://www.regionalscience.org/index.php/Presidents/

${ }^{8}$ Az RSAI-nak jelenlegi, a 2009-2010-es időszakban elnöke Roberta Capello, aki a regionális gazdaságtan professzora a Department of Management, Economics and Industrial Engineering tanszéken, a Politecnico of Milan egyetemen.

${ }^{9}$ A hazai regionális tudományról nemrég jelent meg egy áttekintő tanulmánykötet (Lengyel-Rechnitzer 2009), benne Rechnitzer János elemző írásával (2009).

${ }^{10}$ Méretgazdaságosság (economies of scale) a termelékenység javulása, illetve a termelés átlagköltségének csökkenése, az összes termelési tényező egyidejü, azonos arányú növelése esetén (SamuelsonNordhaus 2000, 725). Lényegében a nagy szériából származó költségelőnyök.

${ }^{11}$ A növekvő mérethozadék (increasing returns to scale): ha az összes termelési tényező egyidejü, azonos arányú növelése esetén ennél az aránynál a kibocsátás növekedési üteme magasabb lesz (Samuelson-Nordhaus 2000, 725). Használatos még a skálahozadék, volumenhozadék kifejezés is.

${ }^{12}$ A monopolisztikus verseny olyan piaci szerkezet, amelyben sok kis eladó hasonló, de nem teljesen azonos, azaz differenciált termékek kínálatával verseng. Ilyen piacon minden vállalat befolyásolhatja bizonyos mértékben saját termékének árát (Samuelson-Nordhaus 2000, 725).

${ }^{13}$ Az 'István, a király' című rockoperából Réka egyik dalának címe.

${ }^{14}$ A Magyar Értelmező Szótár (1978) szerint: „Közelség 1) Valakinek, valaminek térben vagy időben közeli volta. 2) Bensőséges, közeli viszony. 3) Tartalmi, fogalmi stb. rokonság, hasonlóság”. A közelség a magyar nyelvben is kiterjesztett értelmezésủ, nemcsak térbeli közelséget jelent.

${ }^{15}$ A szakirodalomban leggyakrabban három kifejezés, 'organized', 'organizational' és a 'relational' fordul elö, hasonló értelmezési háttérrel. Úgy vélem, hogy a 'szervezett' és a 'szervezeti' közelségek félreérthetők, ezért használom inkább a 'kapcsolati' közelséget.

${ }^{16}$ A Regional Studies 2005. évi 1. (februári) számában a közelség innovatív gazdasági interakciókban betöltött szerepével foglalkozik egy tanulmány-blokk (6 speciális tanulmány), míg a 2008. évi 6. szám tanulmányai az innovációkhoz szükséges átmeneti földrajzi közelségröl (clusters, knowledge gatekeepers, temporary geographical proximity) szólnak. A European Planning Studies 2007. évi 4. számát a periférikus régiókban megfigyelhető innovatív közelségnek, míg a 2008. évi 5. számát a 'francia közelség iskolának' szentelte.

${ }^{17}$ Marshall vezette be a külső méretgazdaságosság alapján az iparági körzet (industrial district) fogalmát is. Iparág és iparági körzet alatt nemcsak ipari tevékenységet értünk, hanem szolgáltatások térbeli tömörülését is (pl. a pénzügyi tevékenységek koncentrálódását a Wall Street-en), aminek talán jobban megfelelne az üzletág kifejezés. Továbbá az 'ág' a magyar szóhasználatban a TEÁOR (ág, ágazat, alágazat stb.) felosztása miatt foglalt, ezért az iparág inkább alágazatnak, avagy más felfogásban szektornak, tevékenységi körnek felel meg.

18 Agglomeráción a regionális tudományban nem egy nagyvárost és vonzáskörzetét értjük, hanem a gazdasági tevékenységek térbeli sürüsödését. Hasonlóan a társadalomföldrajz nemzetközi szakirodalmában az agglomeráció (Gregory et al 2009, 14): „The association of productive activities in close 
proximity to one another. Agglomeration typically gives rise to external economies associated with the collective use of the infrastructure of transportation, communication facilities and other services." Az Oxford Dictionary of Geography (Mayhew 1997) is hasonlóan fogalmaz: „The concentration of activities, usually industries, near to each other, for example in a specialized industrial region, such as 'Silicon Fen'Cambridgeshire, UK, or in a large town or city."

\section{Irodalom}

Acs Z. (2009) Jaffe-Feldman-Varga: The search for knowledge spillovers. - Varga, A. (ed) Universities, Knowledge Transfer and Regional Development: Geography, Entrepreneurship and Policy. Edward Elgar, Cheltenham-Northampton. 36-56. o.

A.Gergely A. (2001) Tér, idö, határ és átmenet. MTA Politikai Tudományok Intézete, Budapest.

Armstrong, H.-Taylor, J. (2000) Regional Economics and Policy. (3 $3^{\text {rd }}$ ed) Blackwell, Malden (MA).

Bailly, A.-Coffey, W.J. (1994) Regional science in crisis: A plea for a more open and relevant approach. - Papers in Regional Science. 73. 3-14. o.

Bailly, A.-Coffey, W.J.-Gibson, L.J. (1996) Regional science: Back to the future? - The Annals of Regional Science. 30. 153-163. o.

Bailly, A.-Gibson, L.J. (2004) Regional science: Directions for the future. - Papers in Regional Science. 83. 127-138. o.

Bangó J. (2008) Útkeresés a posztmodernben. Mundus Magyar Egyetemi Kiadó, Budapest.

Barnes, T.J. (2003) What's Wrong with American Regional Science? A View from Science Studies. Canadian Journal of Regional Science. Spring. 3-26. o.

Bathelt, H. (2008) Knowledge-based clusters: regional multiplier models and the role of 'buzz' and 'pipelines'. - Karlsson, C. (ed) Handbook of Research on Cluster Theory. Edward Elgar, Cheltenham. 78-92. o.

Beaudry, C.-Schiffauerova, A. (2008) Who's right, Marshall or Jacobs? The localization versus urbanization debate. - Research Policy. 2. 318-337. o.

Beluszky P. (2008) Maradékok boltja (Egy visszavonuló levelei). - Tér és Társadalom. 4. 221-228. o.

Benedek J. (2002) A földrajz térszemléletének hullámai. - Tér és Társadalom. 4. 21-39. o.

Benko, G. (1999) Regionális tudomány. Dialóg Campus, Budapest-Pécs.

Boschma, R. (2005) Proximity and Innovation: A Critical Assessment. - Regional Studies. 1. 61-74. o.

Boyce, D. (2004) A short history of the field of regional science. - Papers in Regional Science. 83. 31-57. o.

Capello, R. (2002) Entrepreneurship and spatial externalities: Theory and measurement. - The Annals of Regional Science. 36. 387-402. o.

Capello, R. (2007) Regional economics. Routledge, London and New York.

Capello, R. (2008) Regional economics in its 1950s: recent theoretical directions and future challenges. Annals of Regional Science. 42.747-767. o.

Capello, R. (2009) Space, growth and development. - Capello, R.-Nijkamp, P. (eds.) Handbook of Regional Growth and Development Theories. Edward Elgar, Cheltenham. 33-52. o.

Castells, M. (2005) A hálózati társadalom kialakulása. (I. kötet). Gondolat-Infonia, Budapest.

Combes, P.-Mayer, T.-Thisse, J-J. (2008) Economic geography. The Integration of Regions and Nations. Princeton University Press, Princeton and Oxford.

Cséfalvay Z. (2004) Globalizáció 1.0. Érvek és ellenérvek. Nemzeti Tankönyvkiadó, Budapest.

Csizmadia Z. (2009) Együttmüködés és újitóképesség. Kapcsolati hálózatok és innovációs rendszerek regionális sajátosságai. Napvilág Kiadó, Budapest.

Duranton, G.-Puga, D. (2004) Micro-foundation of urban agglomeration economies. - Henderson, J.V.Thisse, J-F. (eds.) Handbook of Regional and Urban Economics. Cities and Geography (Volume 4). Elsevier, Amsterdam. 2063-2117. o.

Dusek T. (2007) A társadalomföldrajz és a regionális tudomány különbségeiröl. - Tér és Társadalom. 2. 137-140. o.

Dusek T.-Szalkai G. (2006) Az időtér és a földrajzi tér összehasonlítása. - Tér és Társadalom. 2. 47-63. o.

Edwards, M.E. (2007) Regional and urban economics and economic development. Auerbach Publications, New York.

Ejermo, O. (2005) Technological diversity and Jacobs' externality hypothesis revisited. - Growth and Change. 2. 167-195. o. 
Enyedi Gy. (1984) Az urbanizációs ciklus és a magyar településhálózat átalakulása. Akadémiai Kiadó, Budapest.

Enyedi Gy. (1988) A városnövekedés szakaszai. Akadémiai Kiadó, Budapest.

Enyedi Gy. (1996) Regionális folyamatok Magyarországon az átmenet idöszakában. Ember-településrégió sorozat. Hilscher Rezső Szociálpolitikai Egyesület, Budapest.

Enyedi Gy. (2000) Globalizáció és magyar területi fejlődés. - Tér és Társadalom. 1. 1-10. o.

Enyedi Gy. (2003) Alkalmazott földrajz Közép-Európában. - Földrajzi Értesítő. 3-4. 145-160. o.

Enyedi Gy. (2007) A társadalomföldrajz és a regionális tudomány (Hozzászólás Probáld Ferenc cikkéhez). - Tér és Társadalom. 2. 133-135. o.

Enyedi Gy. (2009) Városi világ. - Magyar Tudomány. 3. 295-302. o.

Enyedi Gy. (2010) Terület- és településfejlesztéssel kapcsolatos tudományos kutatások fô irányai és feladatai. - Területi Statisztika. 4. 398-405. o.

Faragó L. (2007) Térstruktúra: térideák és megvalósításuk a településhálózat-fejlesztésben. - Tér és Társadalom. 4. 21-38. o.

Farkas J. (2003) A társadalmi tér elméleti kérdései. - Társadalomkutatás. 2. 167-190. o.

Fujita, M.-Krugman, P.-Venables, A.J. (1999) The Spatial Economy. Cities, Regions, and International Trade. MIT Press, Cambridge (MA).

Fujita, M.-Thisse, J-F. (2002) Economics of Agglomeration. Cities, Industrial Location, and Regional Growth. Cambridge University Press, Cambridge.

Gál Z. (2010) Pénzügyi piacok a globális térben. Akadémiai Kiadó, Budapest.

Gregory, D.-Johnston, R.J.-Pratt, G.-Watts, M.-Whatmore, S. (eds.) (2009) The Dictionary of Human Geography. $\left(5^{\text {th }}\right.$ ed) Wiley-Blackwell, Chichester.

Haggett, P. (2006) Geográfia. Globális szintézis. Typotex, Budapest.

Henderson, V.-Thisse, J-F. (eds.) (2004) Handbook of Regional and Urban Economics. Cities and Geography. (Vol 4) Elsevier, Amsterdam.

Horváth Gy.-Rechnitzer J. (2000) Új tudományterület születése. A regionális tudomány két évtizede. Horváth Gy.-Rechnitzer J. (szerk.) Magyarország területi szerkezete és folyamatai az ezredfordulón. MTA Regionális Kutatások Központja, Pécs. 9-18. o.

Isard, W. (1975) Introduction to Regional Science. Prentice-Hall, Englewood Cliffs.

Isard, W. (2003) History of Regional Science and the Regional Science Association International: The Beginnings and Early History. Springer, Berlin.

Jakobi Á. (2007a) Tér, információ és társadalom: a társadalom területi kutatásának térinformatikai eszköztára. - Tér és Társadalom. 1. 131-143. o.

Jakobi Á. (2007b) Az információs társadalom térbelisége. Regionális Tudományi Tanulmányok 13. ELTE, Budapest.

Johnson, D.K.-Siripong, N,-Brown, A. (2006) The Demise of Distance? The declining role of physical proximity for knowledge transmission. - Growth and Change. 1. 19-33. o.

Knoben, J.-Oerlemans, L. (2006) Proximity and inter-organizational collaboration: A literature review. International Journal of Management. 2. 71-89. o.

Kocsis É.-Szabó K. (2001) Modularitás és változatossági hozadék. - Közgazdasági Szemle. 9. 745-765. o.

Korompai A. (1995) Regionális stratégiák jövökutatási megalapozása. Regionális Tudományi Tanulmányok, 1. ELTE, Budapest.

Krugman, P. (1995) Development, Geography, and Economic Theory. MIT Press, Cambridge (MA).

Krugman, P. (1998) Space: The Final Frontier. - Journal of Economic Perspectives. 2. 161-175. o .

Krugman, P. (2000a) A földrajz szerepe a fejlődésben. - Tér és Társadalom. 4. 1-21. o.

Krugman, P. (2000b) Where in the World is the 'New Economic Geography'? - Clark, G.L.-Feldman, M.P.-Gertler, M.S. (eds.) The Oxford Handbook of Economic Geography. Oxford University Press, Oxford. 49-60. o.

Krugman, P. (2003) Földrajz és kereskedelem. Nemzeti Tankönyvkiadó, Budapest.

Lagendijk, A.-Oinas, P. (eds.) (2005) Proximity, Distance and Diversity. Issues on Economic Interaction and Local Development. Ashgate, Aldershot.

Lengyel B. (2004) A tudásteremtés lokalitása: hallgatólagos tudás és helyi tudástranszfer. - Tér és Társadalom. 2. 51-71. o.

Lengyel B.-Leydesdorff, L. (2008) A magyar gazdaság tudásalapú szerveződésének mérése. - Közgazdasági Szemle. 6. 522-547. o.

Lengyel I. (2003) Verseny és területi fejlödés: térségek versenyképessége Magyarországon. JATEPress, Szeged.

Lengyel I. (2007) Fejlesztési pólusok, mint a tudásalapú gazdaság kapuvárosai. - Magyar Tudomány. 6. 749-758. o. 
Lengyel I. (2008) A közelség alakváltozásai a tudásalapú helyi gazdaságfejlesztésben. - Lengyel I.Lukovics M. (szerk.) Kérdőjelek a régiók gazdasági fejlödésében. SZTE Gazdaságtudományi Kar Közleményei. JATEPress, Szeged. 109-129. o.

Lengyel I. (2010) Regionális gazdaságfejlesztés. Versenyképesség, klaszterek és alulról szervezödő stratégiák. Akadémiai Kiadó, Budapest.

Lengyel I.-Mozsár F. (2002) A külső gazdasági hatások (externáliák) térbelisége. - Tér és Társadalom. 2. 1-20. o.

Lengyel I.-Rechnitzer J. (2004) Regionális gazdaságtan. Dialóg Campus, Budapest-Pécs.

Lengyel I.-Rechnitzer J. (szerk.) (2009) A regionális tudomány két évtizede Magyarországon. Akadémiai Kiadó, Budapest.

Mackinnon, D.-Cumbers, A. (2007) An introduction to economic geography. Prentice Hall, Harlow.

Maier, G.-Kauffman, A.-Vyborny, M. (2008) Is regional science a scientific discipline? Answers from a citacion based social network analysis. SRE-Discussion 2., Institute of Regional Development and Environment, University of Economics and Business Administration, Wien.

Mayhew, S. (1997) Oxford Dictionary of Geography. Oxford University Press, Oxford.

McCann, P. (2007) Observational equivalence? Regional studies and regional science. - Regional Studies. 9. 1209-1221. o.

McCann, P. (2008) Agglomeration economics. - Karlsson, C. (ed.) Handbook of Research on Cluster Theory. Edward Elgar, Cheltenham. 23-38. o.

Mera, K. (2004) Regional Science for what? Policy orientation of WRSA. - The Annals of Regional Science. 38. 349-356.o.

Mészáros R. (2003) Kibertér. A földrajzi tudás új dimenziói. Hispánia, Szeged.

Mészáros R. (2006) A társadalomföldrajz és a regionális tudomány Magyarországon. - Magyar Tudomány. 1. 21-28. o.

Mészáros R. (2008) A kibertér és ami körülötte van. Társadalomföldrajzi megközelités. JATEPress, Szeged.

Mészáros R. (2010) A globális gazdaság földrajzi dimenziói. Akadémiai Kiadó, Budapest.

Moodysson, J. (2008) Principles and practices of knowledge creation: On the organization of „buzz” and „pipelines” in life science communities. - Economic Geography. 4. 449-469. o.

Morgan, K. (2004) The exaggerated death of geography: learning, proximity and territorial innovation system. - Journal of Economic Geography. 4. 3-21. o.

Murdoch, J. (2006) Post-structuralist geography. A guide to relational space. SAGE, London.

Nemes Nagy J. (2003) A regionális tudomány dualitása és paradigmái - hazai tükör. - Tér és Társadalom. 1. $1-17$. o.

Nemes Nagy J. (2007) Kvantitatív társadalmi térelemzési eszközök a mai regionális tudományban. - Tér és Társadalom. 1. 1-19. o.

Nemes Nagy J. (2009) Terek, helyek, régiók. A regionális tudomány alapjai. Akadémiai Kiadó, Budapest.

Nyíri K. (1999) Castells: The Information Age. Könyvismertetés. - Replika. 2. 157-161. o.

Parr, J.B. (2002) Missing Elements in the Analysis of Agglomeration Economies. - International Regional Science Review. 2. 151-168. o.

Pearce, D. (szerk.) (1993) A modern közgazdaságtan ismerettára. Közgazdasági és Jogi Könyvkiadó, Budapest.

Polenske, K.R. (2004) Competition, Collaboration and Cooperation: An Uneasy Triangle in Networks of Firms and Regions. - Regional Studies. 9. 1029-1043. o.

Porter, M.E. (2000) Location, Clusters, and Company Strategy. - Clark, G.L. -Feldman, M.P.-Gertler, M.S (eds.) The Oxford Handbook of Economic Geography. Oxford University Press, Oxford. 253-274. o.

Probáld F. (2007) Társadalomföldrajz és a regionális tudomány. - Tér és Társadalom. 2. 21-33. o.

Queigly, J.M. (2001) The renaissance in regional research. - The Annals of Regional Science. 35. 167-178. o.

Rechnitzer J. (2000) A regionális tudomány és intézményrendszere. - Tér és Társadalom. 2-3. 3-8. o.

Rechnitzer J. (2005) Tükör által el nem homályosítva (a posztmodern a paradigmák, a main stream és a csábítás ördöge a regionális tudományban). - Tér és Társadalom. 3-4. 1-12. o.

Rechnitzer J. (2009) A társadalomtudomány új ága, a regionális tudomány. - Lengyel I.-Rechnitzer J. (szerk.) A regionális tudomány két évtizede Magyarországon. Akadémiai Kiadó, Budapest. 13-24. o.

Rietveld, P.-Vickerman, R. (2004) Transport in regional science: The „death of distance” is premature.Papers in Regional Science. 83. 229-248. o.

Rosenthal, S.-Strange, W. (2004) Evidence on the nature and sources of agglomeration economies. Henderson, J. V.-Thisse, J-F. (eds) Handbook of Regional and Urban Economics. Cities and Geography (Volume 4). Elsevier, Amsterdam. 2119-2171. o.

Samuelson, P.A.-Nordhaus, W.D. (2000) Közgazdaságtan. KJK KERSZÖV, Budapest. 
Stiglitz, J.E.-Sen, A.-Fitoussi, J-P. (2010) A Bizottság jelentése a gazdasági teljesítmény és a társadalmi fejlődés méréséröl. - Statisztikai Szemle. 3. 305-320. o.

Storper, M.-Venables, A.J. (2004) Buzz: face-to-face contact and the urban economy. - Journal of Economic Geography. 4. 351-370. o.

Szirmai V. (2004) Globalizáció és a nagyvárosi tér társadalmi szerkezete. - Szociológiai Szemle. 4. 3-24. o.

Szirmai V. (2005) A városkutatások továbbfejlesztésének szempontjai: az európai várostudományok jövöje. - Tér és Társadalom. 3-4. 43-60. o.

Torre, A. (2008) On the role played by temporary geographical proximity in knowledge transmission. Regional Studies. 6. 869-889. o.

Torre, A.-Gilly, J-P. (2000) On the analytical dimension of proximity dynamics. - Regional Studies. 2. 169-180. o.

Torre, A.-Rallet, A. (2005) Proximity and localization. - Regional Studies. 1. 47-60. o.

Varga A. (2009) Térszerkezet és gazdasági növekedés. Akadémiai Kiadó, Budapest.

Varga A.-Parag A. (2009) Egyetemi tudástranszfer és a nemzetközi kutatási hálózatok szerkezete. Közgazdasági Szemle. 4. 343-358. o.

Vas Zs. (2009) Közelség és regionális klaszter: a szoftveripar Szegeden. - Tér és Társadalom. 3. 127-145. o. 